OPEN ACCESS

Edited by:

Alexander G. Haslberger,

University of Vienna, Austria

Reviewed by: Matteo A. Russo,

San Raffaele Pisana (IRCCS), Italy Francisco José Pérez-Cano, University of Barcelona, Spain

${ }^{*}$ Correspondence: Dong-Kug Cho choidk@kku.ac.kr

Specialty section

This article was submitted to Nutritional Immunology, a section of the journal

Frontiers in Immunology

Received: 15 February 2019 Accepted: 18 April 2019 Published: 10 May 2019

Citation:

Azam S, Jakaria M, Kim I-S, Kim J,

Haque ME and Choi D-K (2019) Regulation of Toll-Like Receptor (TLR) Signaling Pathway by Polyphenols in

the Treatment of Age-Linked Neurodegenerative Diseases: Focus on TLR4 Signaling.

Front. Immunol. 10:1000 doi: 10.3389/fimmu.2019.01000

\section{Regulation of Toll-Like Receptor (TLR) Signaling Pathway by Polyphenols in the Treatment of Age-Linked Neurodegenerative Diseases: Focus on TLR4 Signaling}

\author{
Shofiul Azam ${ }^{1}$, Md. Jakaria ${ }^{1}$, In-Su Kim ${ }^{2}$, Joonsoo Kim ${ }^{1}$, Md. Ezazul Haque ${ }^{1}$ and \\ Dong-Kug Choi ${ }^{1,2 *}$
}

${ }^{1}$ Department of Applied Life Science \& Integrated Bioscience, Graduate School, Konkuk University, Chungju-si, South Korea, ${ }^{2}$ Department of Integrated Bioscience \& Biotechnology, Research Institute of Inflammatory Disease (RID), College of Biomedical and Health Science, Konkuk University, Chungju-si, South Korea

Neuronal dysfunction initiates several intracellular signaling cascades to release different proinflammatory cytokines and chemokines, as well as various reactive oxygen species. In addition to neurons, microglia, and astrocytes are also affected by this signaling cascade. This release can either be helpful, neutral or detrimental for cell survival. Toll-like receptors (TLRs) activate and signal their downstream pathway to activate NF-kB and pro-IL-1 $\beta$, both of which are responsible for neuroinflammation and linked to the pathogenesis of different age-related neurological conditions. However, herein, recent aspects of polyphenols in the treatment of neurodegenerative diseases are assessed, with a focus on TLR regulation by polyphenols. Different polyphenol classes, including flavonoids, phenolic acids, phenolic alcohols, stilbenes, and lignans can potentially target TLR signaling in a distinct pathway. Further, some polyphenols can suppress overexpression of inflammatory mediators through TLR4/NF-кB/STAT signaling intervention, while others can reduce neuronal apoptosis via modulating the TLR4/MyD88/NF-кB-pathway in microglia/macrophages. Indeed, neurodegeneration etiology is complex and yet to be completely understood, it may be that targeting TLRs could reveal a number of molecular and pharmacological aspects related to neurodegenerative diseases. Thus, activating TLR signaling modulation via natural resources could provide new therapeutic potentiality in the treatment of neurodegeneration.

Keywords: polyphenols, MyD88, Toll-like receptor, NF-кB, neurodegenerative disease, inflammasome

\section{INTRODUCTION}

Polyphenols are secondary metabolites of plants and serve to protect against a variety of pathogens, as well as ultraviolet damage. This phytochemical class of compounds also has a potential role in different oxidative stress-induced complications, such as cardiovascular disease, cancer and neurodegenerative diseases (1). Thus, a regular diet comprising frequent intake of polyphenol derivatives has been found to lower the risk of deposition of low-density lipoprotein (LDL), 
preventing endothelial coagulation and hindering atherosclerosis (2-5). Polyphenols are available in different kinds of fruits, vegetables or herbs and act as micronutrients. Approximately 8,000 or more members of this phytochemical group have been identified, and they originate from either phenylalanine or shikimic acid with a common phenolic group in their structural ring (6). Primarily, their classification includes phenolic acid, flavonoids, stilbenes and lignans (6).

However, aging and age-linked neurological complications are frequently observed and reaching epidemic levels due to day-by-day environmental or lifestyle modifications. At $>60$ years of age, different regions of the brain progressively and slowly lose cells due to the overexpression of cytokines, chemokines and neurotoxicity. This pathologic condition is featured by neurodegenerative diseases, such as Alzheimer's diseases (AD), Parkinson's disease (PD), multiple sclerosis (MS), Huntington's disease (HD), and amyotrophic lateral sclerosis (ALS) $(7,8)$. Several etiologies of such neurodegeneration are commonly associated with oxidative stress, neuroinflammation, mitochondrial dysfunction, protein aggregations and apoptotic factor activations (7). As such, researchers have attempted to understand the associated pathogenesis in this regard and to develop treatments; however, current approaches are not particularly promising and only symptomatic because in most neurodegenerative diseases, symptoms appear later. Thus, early preventive measures can interfere with disease progression and decrease suffering. One promising preventive attempt may be the inclusion of polyphenols in the regular diet, an approach that can reduce oxidative stress. The phenolic group of polyphenols interrupt the incessant oxidation in the cell by accepting an electron and forming a stable phenoxyl structure that breaks the formation of reactive oxygen species (ROS) (9). Thus, this group increases plasma antioxidant capacity, consequently reducing lymphocytic DNA damage, protecting cell components from degeneration $(6,10)$ and reducing the risk of oxidative stressinduced degenerative disorders. Moreover, polyphenols stimulate the Nrf2/ARE signaling pathway to enhance endogenous antioxidant component synthesis. This class of compounds also has the potential to modulate NF- $\kappa \mathrm{B}$-promoted neuroprotective activity (11).

Microglial cells and astrocytes are the primary sources of ROS. Microglial activation triggers neurodegeneration by

\footnotetext{
Abbreviations: ND, neurodegenerative diseases; AD, Alzheimer disease; PD, Parkinson disease; MS, multiple sclerosis; HD, Huntington disease; ALS, amyotrophic lateral sclerosis; CD40L, cluster of differentiation 40 ligand; SIRT1, silent mating type information regulation 2 homolog 1 ; SN, substantia nigra; JTF, c-Jun transcription factors; GPx, glutathione peroxidase; GSK-3 $\beta$, glycogen synthase kinase $3 \beta$; CREB, cAMP response element binding proteins; TSG, 2,3,4',5-tetrahydroxystilbene-2-O- $\beta$-D-glucoside; Nrf2, nuclear factor-2; HMGB1, high mobility group box 1 protein; PAMPs, pathogen-associated molecular patterns; DAMPs, damage-associated molecular patterns; PRRs, pattern recognition receptors; MyD88, myeloid differentiation factor 88; IRF3, interferon regulatory factor 3; TRIF, TIR-domain-containing adaptor-inducing interferon- $\gamma$; TRAM, TRIF-related adaptor molecule; IFN, type-I interferon; IKKs, IкB kinase; NPC, neural precursor cells; EGCG, epigallocatechin gallate; IRAK4, interleukin1 receptor-associated kinase-4; TRAF6, TNF receptor-associated factor-6; MKK4, mitogen-activated protein kinase; kinase- 4 IKK $\alpha / \beta$, IкK kinase $\alpha / \beta$; JNK, c-Jun $\mathrm{N}$-terminal kinase; IRF3/7, interferon regulatory factor-3/7.
}

activating and hypersecreting excitotoxic neurotransmitters that reduce ATP and growth factors in injured neurons (12). In that case, a potential anti-oxidant, such as polyphenols, may provide neuroprotection by inhibiting ROS generation and reducing auto-inflammatory responses. Therefore, polyphenols can act as both anti- and pro-oxidants, depending on their highly specific structure and cellular redox context, which may include either increased oxidant scavenging proteins or reduced oxidized proteins. For example, EGCG (Epigallocatechin gallate) improves mitochondrial function via antioxidative action (13). Besides polyphenols' ROS-scavenging ability, metal chelation and enzyme regulation also forms part of the mechanism of antioxidative action (14). Additionally, polyphenols can modulate the important pathogenesis of ND with its pleiotropic activity, including antioxidant properties. For example, polyphenols can modulate the NF- $\kappa \mathrm{B}$-mediated pathway to provide neuroprotection. In addition, polyphenols attenuate cognitive impairment, $\mathrm{A} \beta$-aggregation and proinflammatory cytokines (15). While the actions of cytokines are well-known, including their inhibition exerting neuroprotection, in some cases, inhibition may exacerbate neuronal damage (16-18). Cytokine response in the CNS requires activation through a specific motion, while TLRs, as a part of the innate immune system, also regulate cytokine responses in the CNS. Therefore, this review aims to provide insight into natural compound-based TLR signaling intervention toward inflammatory cytokine overexpression, a process that may impact future neurodegeneration therapy.

\section{Polyphenols: Overview on Bioavailability and Permeability Through BBB}

Naturally occurring polyphenols include four major classes: flavonoids, phenolic acid, stilbenes and lignans, with each member being further divided into different subgroups. Among these compounds, the flavonoids are the most comprehensive group, with a structural backbone of $\mathrm{C}_{6^{-}}$ $\mathrm{C}_{3}-\mathrm{C}_{6}$ and that contain an oxygenated heterocycle (19). Flavonoids are further sub-divided into 14 groups, including flavones, dihydroflavones, isoflavones and anthocyanidines (20). However, the pharmacological activity of different polyphenols depends on their affinity toward a complex formation with other groups, such as alcohols, acids or sugar, as well as their bioavailability (21).

The bioavailability of polyphenols widely differs from person to person due to the glycosylation pattern and degree of polymerisation. Because natural polyphenols often exist as esters, polymers or glycosylated forms, they need to go through hydrolyzation for absorption. In that case, gut microflora would help by the deglycosylation, dehydroxylation, and demethylation of polyphenols (22). For example, flavonoids are the most poorly absorbed glycosides that require deglycosylation in the small intestine by $\beta$-glucosidases enzymes to convert into aglycones and then be absorbed. The availability of aglycones in the circulation also differs due to the Phase I and II metabolism of oxidized and conjugated flavonoids $(22,23)$. 
Absorption and bioavailability of polyphenols is also affected by biotransformation. For example, curcumin, after ingestion by mice, was detected in plasma within $15 \mathrm{~min}$ as dihydrocurcumin. However, at $1 \mathrm{~h}$, it peaks as tetrahydrocurcumin and at $6 \mathrm{~h}$, curcumin decreases as monoglucuronide (24). Another study detected trace amounts of curcumin and its metabolites in the circulation and organs of healthy humans, which showed a low impact on the modulation of chemotherapy-induced apoptosis (25). On the other hand, resveratrol transformed into glucuronoids and sulfates within 15 min of oral consumption and circulated for more than $9 \mathrm{~h}$ with a bioavailability of $1 \%$ following metabolism (26). Further, other dietary components, such as carbohydrate, protein, fats, and alcohols also affect absorption and the bioavailability of polyphenols. Fats in the diet enhance polyphenol absorption, while serum albumin potentiates cellular uptake and delays elimination.

Due to poor absorptivity, rapid metabolism and elimination, polyphenols have highly selective permeability across the bloodbrain barrier (BBB) that limits their bioavailability in the CNS as well as their therapeutic efficacy. Although polyphenols can alter brain function through improving cerebral blood flow (27), changing multidrug-resistant protein-dependent influx and efflux mechanisms $(28,29)$ and direct modification of neuronal and glial activities, to exert these activities, they must also move inside the CNS and at an effective concentration. The BBB, in that case, is the critical regulator, which controls the entry and retention of nutraceuticals in the brain. There are several transport systems at the $\mathrm{BBB}$, and some are particularly specific to allow nutrients, such as amino acids, glucose, vitamins and iron, for both influx and efflux into the brain. The same principle also applies for polyphenols to enter into the brain. However, due to their variability in stereochemistry and interaction affinity with efflux transporters, such as P-glycoprotein (PGP) at the BBB, their availability in the brain also differs (30). One flavonoidnaringin-has been detected at an effective concentration in the rat brain when co-administered with PGP inhibitors, but on peripheral administration it was undetected (31).

Permeability through the $\mathrm{BBB}$ may also vary due to the degree of lipophilicity. In that case, less polar polyphenols or their metabolites have increased permeability into the brain compared to more polar ones (32). For instance, quercetin3-O-glucuronide, a red wine metabolite, was detected at substantial levels in the $\mathrm{Tg} 2576 \mathrm{AD}$ mice brain after chronic oral administration. That resulted in a significant decrease in $A \beta$ generation and toxicity, consequently improving hippocampusassociated synaptic deficits (33).

The form of administration is also crucial to improve polyphenol bioavailability. Co-administration of $\alpha$-tocopherol with EGCG, quercetin and rutin in the diet synergizes quercetin transport through the BBB but not the EGCG. Curcumin may provide a particularly suitable example for understanding the limitations to achieve therapeutic potential in vivo because its bioavailability is insufficient; thus, several delivery systems, such as nanoparticles, liposomes and micelles failed to improve its bioavailability (34). Hence, co-administration with piperine increased curcumin concentrations in the brain at $48 \mathrm{~h}$ compared to the kidney (5.87 vs. $1.16 \mathrm{mg}$ ) (35). On the other hand, oxyresveratrol improved protection against 6-OHDA better than resveratrol because it is $\mathrm{BBB}$ permeable and water soluble (36). Similarly, bioavailability of EGCG has been improved by using it in a pro-drug form [fully acetylated EGCG (pEGCG)], as well as when tested on 6-OHDA induced SH-SY5Y neuroblastoma cells. The results demonstrated an improved protection by pEGCG more than EGCG, most likely due to the activation of the Akt pathway and reduced caspase- 3 activity (37). As such, improvisation in administration strategy would improve the pharmacotherapeutic potentiality of polyphenols for neurodegeneration.

\section{Polyphenols: Signaling Interference for Neuroprotection}

The most common pathological feature of $\mathrm{AD}$ progression is $\mathrm{A} \beta$ aggregation. Several reports suggest that different polyphenols are involved in the amelioration of $\mathrm{AD}$ by reducing $\mathrm{A} \beta$-plaques. For example, some in vivo studies report that tea polyphenol can inhibit acetylcholinesterase as well as $\mathrm{A} \beta$-aggregation $(38,39)$. Similarly, polyphenols extracted from grape seeds significantly attenuated oligomerized $\mathrm{A} \beta$-peptide and neutralized tau protein folding to recover from cognitive dysfunction, both in vitro and in vivo (40-45). In a transgenic mouse model, tannic acid reduced $A \beta$-deposition via lowering $\beta$-carboxyl terminal amyloid precursor protein cleavage and controlling neuronal inflammation (46), while 7, 8-dihydroxyflavone activates TR$\mathrm{KB}$ (tyrosine receptor kinase $\mathrm{B}$ ) and reduces $\beta$-secretase enzyme during $A \beta$-synthesis (47), thus demonstrating recover memory in an $\mathrm{AD}$ model. However, a study of rutin on SH-SY5Y neuroblastoma cells revealed a substantial decline in oxidative stress, glutathione disulfide formation and cytokines, such as TNF- $\alpha$ and IL-1 $\beta$ (48). Luteolin also showed a similar effect by attenuating microglial activation in an LPS-induced primary neuron-glia study (Table 1) (51).

In a study using SH-SY5Y cells, oxyresveratrol (36) enhanced the SIRT1 (silent mating type information regulation 2 homolog 1) gene and downregulated caspase-3, JNK and JTF (c-Jun transcription factors) to reduce neuronal damage. Similar neuroprotective action was demonstrated using ferulic acid via JNK pathway downregulation in an ischemia/reperfusioninduced mice model (62). In contrast, quercetin protects neurons by stimulating glutathione peroxidase $(\mathrm{GPx})$, superoxide dismutase (SOD), $\mathrm{Na}(+)$, and $\mathrm{K}(+)$-ATPase (62) and suppresses apoptosis in an in vitro PD model. Furthermore, it also reduced dopaminergic cell loss in rat striatum (Table 1) (54). Other polyphenols, such as baicalein, kaempferol, caffeic acid, and EGCG $(52,63-65)$ also revealed neuroprotective action in $\mathrm{PD}$, both in vitro and in an animal model study. For example, mulberry fruit extracts modulated Bcl-2, caspase- 3 and Bax, and showed an anti-apoptotic effect in an experiment on SH-SY5Y cells (66). Resveratrol was reported to have significant therapeutic value to activate SIRT1 in brown adipose tissue in a study on an N171-82Q transgenic mouse model for HD (63). Also, using an encephalomyelitis mouse model, resveratrol was found to inhibit neural loss without inducing immunosuppression (67). Juglanin, a flavonol 
TABLE 1 | Effect of different polyphenols in various neurodegenerative models (49).

\begin{tabular}{|c|c|c|c|c|}
\hline $\begin{array}{l}\text { Different type and } \\
\text { dose of polyphenols }\end{array}$ & $\begin{array}{l}\text { Dose and mode of } \\
\text { administration }\end{array}$ & Model used & Results obtained & References \\
\hline Apigenin & $\begin{array}{l}10 \mu \mathrm{M} \text { and } 20 \mathrm{mg} / \mathrm{kg} \text {; oral } \\
\text { gavage }\end{array}$ & $\begin{array}{l}\text { BV-2 microglial cell and ischemic } \\
\text { mice }\end{array}$ & $\begin{array}{l}\text { Suppressing p38 mitogen-activated protein kinase } \\
\text { (MAPK), c-Jun N-terminal kinase (JNK) phosphorylation }\end{array}$ & $(50)$ \\
\hline Luteolin & $5 \mu \mathrm{M}$ & LPS-induced primary neuron-glia & $\begin{array}{l}\text { Attenuated microglial activation and overproduction of } \\
\text { TNF- } \alpha, \mathrm{NO} \text { and superoxide }\end{array}$ & $(51)$ \\
\hline Kaemferol & $30 \mu \mathrm{M}$ & $\begin{array}{l}\text { Rotenone-induced SH-SY5Y cell } \\
\text { and primary neuron }\end{array}$ & Enhanced mitochondrial output by autophagy & $(52)$ \\
\hline Myricetin & $10^{-9} \mathrm{~mol} / \mathrm{L}$ & $\mathrm{MPP}^{+}$-treated MES23.5 cells & $\begin{array}{l}\text { Attenuate cell loss, intracellular ROS, and } \\
\text { phosphorylation of MAPK kinase } 4 \text { and JNK }\end{array}$ & $(53)$ \\
\hline Quercetin & 25-75 mg/kg; i.p & Rotenone-induced rats & Reducing dopaminergic cell loss in striatum & $(54)$ \\
\hline Catechin & 10-30 mg/kg; i.p & 6-OHDA-lesioned rats & $\begin{array}{l}\text { Improved locomotor activity and rotational behavior, and } \\
\text { increased dopamine content }\end{array}$ & $(55)$ \\
\hline Naringenin & $\begin{array}{l}80 \mu \mathrm{M} \text { and } 70 \mathrm{mg} / \mathrm{kg} \text {; oral } \\
\text { gavage }\end{array}$ & $\begin{array}{l}6-O H D A \text {-induced SH-SY5Y cell } \\
\text { and mice }\end{array}$ & $\begin{array}{l}\text { Increased Nrf2 protein and protect nigrostriatal } \\
\text { dopaminergic neuron in neurodegeneration }\end{array}$ & $(56)$ \\
\hline Theaflavin & 10 mg/kg; oral gavage & MPTP-induced mice & $\begin{array}{l}\text { Reducing oxidative stress and improving motor function } \\
\text { and dopaminergic expression in striatum and substantia } \\
\text { nigra }\end{array}$ & $(57)$ \\
\hline Silymarin & $1-10 \mu \mathrm{g} / \mathrm{kg}$; i.v. & $\begin{array}{l}\mathrm{Cl} / \text { Required-induced rat, stroke } \\
\text { model }\end{array}$ & $\begin{array}{l}\text { Ameliorate oxidative and nitrosative stresses and } \\
\text { inflammation-mediated tissue injury impeding activation } \\
\text { of proinflammatory transcription factors NF-кB and } \\
\text { STAT-1 }\end{array}$ & $(58)$ \\
\hline Juglanin & 10-30 mg/kg; i.p. & LPS-induced C57B/L6 PD mice & $\begin{array}{l}\text { Betterment of neuroinflammation-related memory } \\
\text { impairment via interfering with TLR4/NF-кB signaling }\end{array}$ & (59) \\
\hline Rutin & $2-20 \mu \mathrm{M}$ & $\begin{array}{l}\text { AD model using SH-SY5Y } \\
\text { neuroblastoma cells }\end{array}$ & $\begin{array}{l}\text { Modulates production of proinflammatory cytokines by } \\
\text { decreasing TNF- } \alpha \text { and IL-1 } \beta\end{array}$ & $(48)$ \\
\hline 7, 8-dihydroxyflavone & 5 mg/kg; i.p. & 5XFAD mice of AD model & $\begin{array}{l}\text { TrkB activation and improved AD-associated memory } \\
\text { deficits; reductions in BACE1 expression and } \\
\text { A } \beta \text {-aggregation }\end{array}$ & $(47)$ \\
\hline Xanthohumol & 0.2 and 0.4 mg/kg; i.p. & MCAO-induced ischemic rats & $\begin{array}{l}\text { Inhibits inflammatory responses via HIF- } 1 \alpha \text {, iNOS } \\
\text { expression reduction, and reduced apoptosis through } \\
\text { impeding TNF- } \alpha \text {, active caspase- } 3\end{array}$ & $(60)$ \\
\hline Fisetin & 50 mg/kg; i.p. & MCAO-induced ischemic mice & $\begin{array}{l}\text { Protected brain tissue against ischemic reperfusion } \\
\text { injury; inhibited infiltration of macrophages and dendritic } \\
\text { cells into ischemic hemisphere; suppressed TNF } \alpha \\
\text { production }\end{array}$ & $(61)$ \\
\hline
\end{tabular}

CI/R, cerebral ischemic/reperfusion; MCAO, middle cerebral artery occlusion.

derivative, in LPS-induced C57B/L6 mice potentially modulated IL- $1 \beta$ and TNF- $\alpha$, and ameliorated neuroinflammation-related memory impairment, and neurodegeneration through impeding TLR4/NF-кB (59).

Dietary polyphenols modulate the NF- $\kappa$ B inflammatory pathway and attenuate $A \beta$-toxicity. Different flavonoids, such as quercetin, apigenin, and luteolin have been reported to suppress the NF- $\kappa$ B-pathway and result in inhibition of $A \beta$ (68). Moreover, the isoflavone extracted from soybean reduced memory impairment in a neurodegenerative rat model via blocking NF- $\kappa \mathrm{B}$ expression (69), while resveratrol and baicalin attenuated $A \beta$-induced neuronal inflammation through downregulating NF- $\mathrm{B}$ signaling $(70,71)$. Thus, NF- $\mathrm{B}$ is important not only in inflammation, but also for cell death events in cerebral ischemic injury. Silymarin, a flavonoid derivative, has been shown to protect against cerebral ischemia by inhibiting NF$\kappa \mathrm{B}$ and STAT-1 (signal transducer and activating transcription1) activation in cerebral ischemic/reperfusion-induced rats, in a dose-dependent manner (1-10 $\mu \mathrm{g} / \mathrm{kg}$, i.v.) (58, 72). Apigenin also provided a significant neuroprotective effect in an ischemic mice model via suppressing JNK phosphorylation (50), whereas $20 \mathrm{mg} / \mathrm{kg}$ of apigenin reduced cerebral infarct volume significantly (Table 1).

Similarly, 2,3,4',5-tetrahydroxystilbene-2-O- $\beta$-D-glucoside (TSG) of Polygonum multiflorum provides neuroprotection in cerebral ischemia by inhibiting NF- $\kappa \mathrm{B}$-signaling and activating SIRT1 $(41,73)$. Quercetin also inhibits NF-кB to protect the brain from oxidative stress or hypoxic damage (74), and a similar effect was demonstrated by catechin hydrate, baicalin, and fisetin (Table 1). Moreover, these phytochemicals were also found to inhibit IL- $\beta$ and TNF- $\alpha$ proinflammatory cytokine expression $(61,75,76)$. Catechin also improved locomotion and increased dopamine in a 6-OHDA-lesioned rat (55). Continual investigation of polyphenols confirms their role as immunomodulatory agents because they can control inflammatory stimuli via downregulating NF-кB expression (46). 
However, resveratrol demonstrated increasing Nrf2 (nuclear factor-2) expression. The Nrf2-pathway is involved in p53 gene expression, which leads to antioxidant protein encoding $(46,77)$. Further, resveratrol increases HO-1 (heme oxygenase1) expression and downregulates the caspase- 3 apoptotic enzyme (78). Similarly, protective action was also revealed by epicatechin in stroke and oxidative stress via upregulating Nrf2 (79). Additionally, a prenylated chalcone, xanthohumol, inhibits the HIF-1 (hypoxia-inducible factors-1) pathway, leading to neuroprotection (Table 1) (60). In a 6-OHDA-induced SH-SY5Y cell study, naringenin increased Nrf2 to protect dopaminergic neurons, while also providing the same effect in a neurodegenerative mice model as well (56).

\section{Toll-Like Receptors: Signaling and Expression in CNS}

Toll-like receptors (TLRs) were first identified in the protein content in Drosophila. Later, their importance in providing innate immunity against microbial infection was recognized (80), and within the family, TLR4 is the first identified mammalian homolog. Unlike adaptive immunity, innate immunity is the first line of defense against anonymous pathogenic invasion, relying on molecular determinant sensing of, for example, pathogenassociated molecular patterns (PAMPs) (81-84). TLRs are a member of the pattern recognition receptor (PRR) group, a large group that includes both intracellular and extracellular receptor families, and sense PAMPs or DAMPs (damage-associated molecular patterns). TLR members are mostly expressed in microglia rather than astrocytes and neurons. However, in certain conditions, some members are expressed in astrocytes and a few in neurons, such as viral- or LPS-induced N9 microglia expressing TLR2 and differentiating astrocytes expressing TLR7 (85). Likewise, TLR4, although expressed in microglia often, are also produced in astrocytes and neurons in response to bacterial LPS (Table 2) (87, 88).

A recent study suggests that increased TLR expression in the neuron can be or is probably linked with different physiological and pathological conditions. Analysis of a teratoma-forming cell line NT-2 (Human NTera2) found mRNA expression for TLR1, 2, 3, and 4; mRNA expression of TLR1-9 and protein expression

TABLE 2 | Expression of different Toll-like receptors in the nervous system.

\begin{tabular}{lccc}
\hline Toll-like receptors & Microglia & Astrocyte & Neuron \\
\hline TLR1 & + & - & - \\
TLR2 & + & + & - \\
TLR3 & + & - & + \\
TLR4 & + & + & + \\
TLR5 & + & - & - \\
TLR6 & + & - & - \\
TLR7 & + & - & + \\
TLR8 & + & - & + \\
TLR9 & + & + & + \\
\hline
\end{tabular}

"+," expressed; "-," expression not detected (86). for 2-4 from rat primary neuronal cells was also evident (89-91). Additionally, an in vivo study on murine mice showed mRNA expression of TLR1-8 (92) and the neuronal expression of TLR2 and 6 , as well as in pathogenic conditions, such as parasitic infection, TLR2, 4 and 6-8 were expressed (92). Some researchers have found that both human and rat inflammatory neurons coexpress TLR4 and CD14, a result which may be due to LPS action through TLR4/CD14 complex formation (93). However, TLR3 can be expressed in both central and peripheral neurons (94).

TLR signaling is complex and depends on other protein and co-receptor pathway activation. Most members depend on the MyD88 (myeloid differentiation factor 88) pathway, except for TLR3 and TLR4. Both of them are unique in their functionality to activate IRF3 (interferon regulatory factor 3). For example, TLR4 activation through the MyD88-independent pathway also activates and recruits TRIF (TIR-domain-containing adaptorinducing interferon- $\gamma$ ) and TRAM (TRIF-related adaptor molecule). Further, the signal cascade activates NF- $\kappa$ B and IRF3, and initiates IFN (type-I interferon) production. TLR3 activates through a TRIF-dependent pathway that recruits IKKs (ІкB kinase), TBK1, and IKKE to begin activation of IRF3, and releases type-I IFN into vesicles (Figure 1) $(91,95)$. This pathway also activates IRF2 via phosphatidylinositol 3-kinase and AKT (91, 96). Other members, such as TLR7, 8 and 9, can also activate type-I IFN through a MyD88-dependent pathway (Figure 1).

Different descriptions in the above figure indicate that TLR2 and 4 affect neuronal differentiation and both are expressed in adult neural stem cells (97). Indeed, TLR4's absence enhances proliferation and neuronal differentiation, while the lack of TLR2 damages hippocampal neurogenesis (98). Both TLR2 and 4 modulate the cell fate of neuronal progenitors (91) via MyD88 and NF- $\kappa \mathrm{B}$ signaling (Figure 1). However, NF- $\kappa \mathrm{B}$-dependent TLR signaling in neuronal cells is highly specific and their signaling in differentiated neurons has yet to be determined.

Furthermore, with respect to TLRs along with NOD-like receptor (NLRs) signals for inflammasome activation, both are almost identical in their structure and have similarities in the component and signaling pathways. However, following inflammasome activation, caspase- 1 signaling cascade also becomes involved and mature IL- $1 \beta$ is released into extracellular vesicles. TLR activation by various ligands also leads to the recruitment of downstream pathway signaling via the MyD88 adaptor and activates NF- $\kappa \mathrm{B}$, which expresses the $31-\mathrm{kDa}$ inactive precursor pro-IL-1 $\beta$, in the cytosol. Meanwhile, inflammasome activates caspase- 1 as an inactive $45-\mathrm{kDa}$ zymogen, which is later catalyzed and activates. Thus, this compound comprises p20 and p10 subunits, both of which are assembled into a heterotetramer. The active caspase- 1 cleaves pro-IL-1 $\beta$ and transforms into a 17 $\mathrm{kDa}$ biologically active IL-1 $\beta$. Similarly, caspase- 1 also cleaves pro-IL18, which unlike pro-IL-1 $\beta$, is constitutively expressed $(99,100)$.

\section{TLRs: Intricate Role in Neurodegenerative Diseases}

A number of studies on inflammatory markers have demonstrated the involvement of TLRs in aging-related 


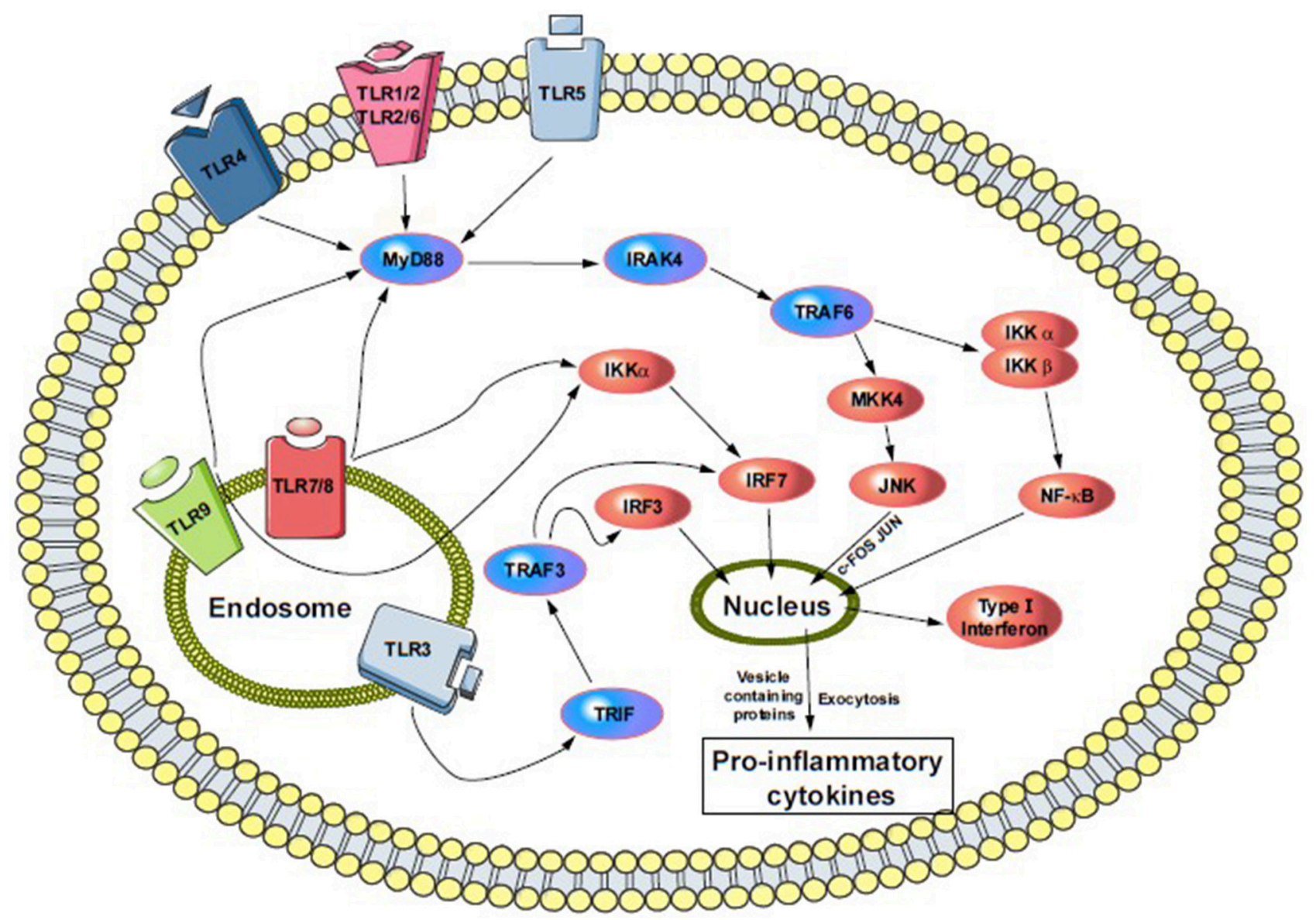

FIGURE 1 | Cell surface and endosomal signaling pathway of TLRs. TLR4, TLR5, and heterodimers TLR1/2 and TLR2/6 sense bacterial invasion and initiate intracellular TLR-signaling pathway. Following the activation, each of them recruits several adaptors in the cytoplasm and activate MyD88-downstream. That means the activation of IRAK4 and phosphoryl IRAK1 that then bind to TRAF6 (not shown). TRAF6 then recruit MKK4 and IKK $\alpha / \beta$ pathway, where MKK4 initiate JNK and activate c-FOS and JUN, and push into the nucleus. While IKK $\alpha / \beta$ activates NFKB and its pro-inflammatory subunits and moves into the nucleus, similarly, endosomal TLRs (TLR3, 7-9) triggers the NFKB and MAPK pathways via involving MyD88 and IRAK4. Additionally, TLR3, MyD88 independently, recruit TRIF-pathway leading to the phosphorylation and dimerization of IRF7. Both, surface and endosomal pathway ultimately result in a production of type I interferon and release of proinflammatory cytokines. MyD88, myeloid Differentiation primary response 88; IRAK4, interleukin-1 receptor-associated kinase-4; TRAF6, TNF receptor-associated factor-6; MKK4, mitogen-activated protein kinase kinase-4; IKK $\alpha / \beta$, IKK kinase; JNK, c-Jun N-terminal kinase; TIRF, TIR-domain-containing adapter-inducing interferon- $\beta$; IRF3/7, interferon regulatory factor- $3 / 7$.

neurodegenerative disorders, such as $\mathrm{AD}$, ischemic strokes and multiple sclerosis. With age, the brain's pro-inflammatory gene transcription upregulates; therefore, TLR transcription levels change and participate in age-linked neurodegeneration. Moreover, they are also involved in brain trauma following injury, where glial cells activate and express different cytokines and chemokines near the injury area. In a mouse model of brain injury, TLR2 was found upregulated by microglia in the hippocampus zone. In contrast, TLR2 deficits reduce microglial activation, cytokine and chemokine expression $(101,102)$.

TLR4 is also profoundly involved in the glial cell expression and activation of NF- $\mathrm{kB}$, as well as initiation of inflammatory cytokines, such as TNF- $\alpha$, IL-1 $\beta$, and IL- 6 production in the brain in different injured animal models (103-106). Both TLR2 and 4 signaling are involved in the activation of glial cells and other inflammatory cytokines and are responsible for inflammation in the injured brain (107). However, in glioma-a glial cell tumor-TLR9 is expressed significantly and was found to be beneficial in a clinical study (Figure 2) (109-111).

\section{TLR Involvement in AD}

The most common pathophysiology of $\mathrm{AD}$, an age-related neurodegenerative disorder, is the deposition of $A \beta$-plaques in the hippocampal region of the brain. Several AD model studies have also discussed the involvement of TLRs. For example, a survey showed significant TLR4 expression in glial cells surrounded by $\mathrm{A} \beta$-plaques (112-114), with TLR4 polymorphism being proposed to have a protective role in $\mathrm{AD}(113,115)$. Although the effects of TLR4-knockout on behavior or disease progression are yet to be documented, microglia-mediated TLR4 


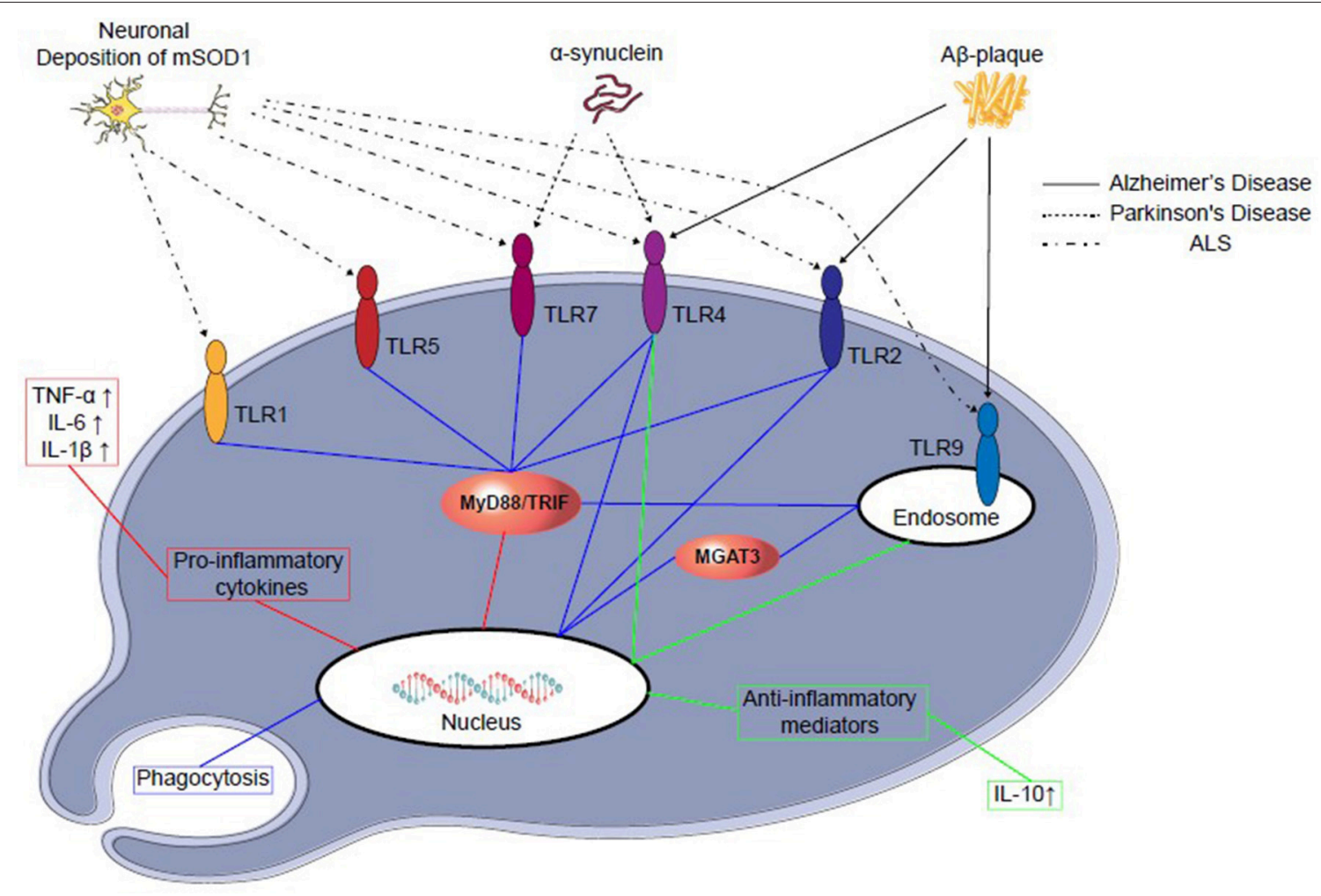

FIGURE 2 | TLRs-signaling in microglial cells in different neurodegenerative disease progression. Abnormal amyloid deposition in different neurodegenerative diseases may activate microglial cells through TLRs. Microglial activation may lead to further neuronal damage through secretion of proinflammatory cytokines (red), such as IL-6 and TNF- $\alpha$, or neuroprotection by secretion of anti-inflammatory cytokines (green), such as IL-10, which may prevent further neuronal death. Furthermore, recent reports suggest TLRs 2, 4, and 9 signaling may modulate the phagocytosis (blue) and clear the neurotoxic amyloid deposition (108). A $\beta$ stimulation, mononuclear cells of normal subjects up-regulate the transcription of $\beta-1,4$-mannosyl-glycoprotein $4-\beta$-Nacetylglucosaminyltransferase (MGAT3).

may be less efficient in a TLR4-knockout model to clear A $\beta$ plaques, leading to the overproduction or aggregation of $\mathrm{A} \beta(116$, 117). It is evident that mouse microglia aggregate $A \beta$ via TLR4 and cause neuronal death (115); thus, microglia require TLR4 for LPS-induced $A \beta$ uptake $(112,117)$. As well, neurons, with the help of TLR4, respond to $A \beta$ and $A D$-linked peroxidation and result in apoptosis (115).

TLR2 deficiency, however, aggravates cognitive impairments in an $\mathrm{AD}$ mouse model. This effect may be reversed by TLR2-expressing bone marrow-derived cells that can stimulate microglial clearance of $A \beta$ from the brain $(118,119)$. Therefore, TLR2 may respond as bone-marrow-derived immune cells to protect from $A \beta$-aggregation. Furthermore, TLR2, TLR4, or TLR9 activating ligands have been reported to increase the uptake of $A \beta$ by a microglial cell line (117). Another in vivo study reports that TLR2 and 4 are also required to activate microglia-mediated $A \beta$-plaques (120). Additionally, exposure of microglia to the TLR9 ligand, CpG DNA, protects neurons against $A \beta$ toxicity and reduces $A \beta$ aggregation-mediated memory impairment in mice $(119,121)$. Collectively, data on multiple TLRs suggest their activation in the $\mathrm{AD}$ brain cells and the well-known role that they have. For example, microglial TLR2, 4 and 9 may counteract the disease process by enhancing $A \beta$ clearance, while activation of TLR4 in neurons can aggravate the condition with initiating oxidative stress and $A \beta$ toxicity. Due to increased knowledge gathered with respect to the role of neuronal TLR4 in AD, it is important to explore this receptor function further in the $\mathrm{AD}$ induced animal model or human tissue/cell line. As such, we can differentiate glial-mediated TLR4 responses from neuronal responses, as well as its role in the association of disease-specific protein aggregation and neuroinflammation or apoptosis.

\section{TLR Involvement in PD}

The various views regarding etiology of PD suggest that misfolded $\alpha$-synuclein activates microglial cells, leading to inflammation, oxidative stress and finally, neurodegeneration. The misfolded $\alpha$-synuclein is released from neural cells or oligodendrocytes, also known as PAMPs or DAMPs, by microglial TLR2 that ultimately activates the downstream pathway of MyD88 and NF- $\mathrm{kB}$, triggers TNF- $\alpha$, IL- $1 \beta$ and increases selective TLR expression (122-124). In one study, TLR4 has been found to interact with $\alpha$-synuclein along with its uptake, proinflammatory cytokine release and enhancing oxidative stress (125). An MPTP-induced PD mouse model analysis interpreted neuroprotection due to the genetic absence of TLR4, supporting the significant role of TLR4 in the generation and progression of PD (126). Interestingly, TLR4 absence protected from dopamine downregulation with an increase 
in dopamine transport activity and significantly reduced $\alpha$ synuclein-positive neurons in an MPTP-induced PD model. In that study, the absence of TLR4 also modulated NF-кB, AP-1, and NLRP3 inflammasome pathways, thus reducing the development of PD-associated neuroinflammation (127). However, the role of TLR2 and 4 during the progress of PD is particularly convincing, although complicated. Their activation of microglia can trigger neurotoxicity, while in other cases, they might be necessary to clear misfolded $\alpha$-synuclein and act as a neuroprotector (Figure 2 and Table 3) (115). Therefore, both of them could be a potential therapeutic target for PD.

\section{TLRs Involved in Cerebral Ischemia/Stroke}

The involvement and pathway of innate immunity in the generation of ischemic tissue has gained significant attention among neuro-researchers in various fields in recent years. According to them, microglial activation is the main reason behind inflammation following cerebral ischemia, and TLR members control this activation to a significant degree (131). Furthermore, TLR2 and TLR4 are the most common in this regard, as they are thought to liberate pro-inflammatory cytokines with respect to immune response; thus, exacerbate ischemic injury and subsequent neuronal damage result.

During a stroke, blood flow is eventually reduced and generates several conditions, such as ionic imbalance, acidosis and excitotoxicity (132) due to lack of oxygen and glucose. Sequentially, the damage of cellular constituents and release of DAMPS that activate specific TLRs occurs (133). In experimental animals as well as in stroke patients, it has been shown that HMGB1, a DAMP protein and also a ligand of TLR2 and TLR4, is increased in serum (134-136). Also, anti-HMGB1 antibody demonstrates a significant reduction in the aggravation of ischemic damage via attenuating cytoplasmic MCAO (middle cerebral artery occlusion) $(134,137,138)$. However, following cell death, Prx (peroxiredoxin protein) is released into the extracellular compartment and acts as a DAMP. Moreover, it activates TLR2 and TLR4, leading to inflammation through cytokine overproduction. Likewise, administration of the Prx antibody just after experimentally induced stroke significantly reduces infarct volume, indicating that Prx also activates TLR signaling to intensify cerebral ischemic injury $(139,140)$. The majority of TLR-focused research has used either a rat or mouse model, and most of them target TLR2 and TLR4. One study demonstrated that TLR2 was markedly upregulated in the mouse cortex and TLR2 knockout mice showed increased infarct volume and mortality compared to wild-type mice (139). In a more recent study, deficiency of TLR2 was found to reduce ischemic volume at an early stage; however, the volume later increased significantly in comparison to wild-type mice, indicating that TLR2 deficiency in the brain can delay ischemic lesions (141).

Similarly, another study involving TLR4-deficient mice reported reduced damage compared to controls following ischemia (142), or permanent occlusion of the middle cerebral artery (143). Meanwhile, several clinical studies also noted the critical role of TLRs in a stroke patient, particularly the involvement of TLR4 polymorphism in terms of stroke prevalence $(130,144)$. Some research also found a significant rise in TLR2 and TLR4 on peripheral monocyte after stroke (145147). Together, these studies indicate that TLR2 and TLR 4 play a critical role in cerebral ischemia/reperfusion injury and that their activation leads to the exacerbation of brain damage. Along with TLR2 and TLR4, increased TLR7 and TLR8 also has been noticed in blood samples of deteriorating stroke patients, but no role has been reported for TLR3 or TLR9 in ischemic injury $(148,149)$.

\section{TLRs Involved in Multiple Sclerosis (MS)}

TLRs are always decisive for their involvement in different neurological diseases, and several pieces of evidence suggest their critical role in the pathogenesis of MS. TLRs have been found to be expressed in the glial cells of CNS of patients suffering from MS (150, 151). Moreover, TLR2 expression is upregulated in peripheral blood mononuclear cells (PBMCs)

TABLE 3 | TLR expression in different neurodegenerative disorders and their documented role.

\begin{tabular}{|c|c|c|c|c|}
\hline Disease & TLRs expression & Animal model & Human model & References \\
\hline \multirow[t]{4}{*}{ Alzheimer's disease } & TLR2 $\uparrow$ & Both beneficial and deleterious & Beneficial & $(115,120,128)$ \\
\hline & TLR4 $\uparrow$ & Both beneficial and deleterious & N/A & \\
\hline & TLR7 个 & TLR7 knockout improved spatial learning & N/A & \\
\hline & TLR9 $\uparrow$ & Reduced A $\beta$-aggregation & $\mathrm{N} / \mathrm{A}$ & \\
\hline \multirow[t]{4}{*}{ Parkinson's disease } & TLR2 $\uparrow$ & Deleterious & Deleterious & $(115,128)$ \\
\hline & TLR4 $\uparrow$ & Deleterious & Deleterious & \\
\hline & TLR5 $\downarrow$ & Cognitive impairment & $\mathrm{N} / \mathrm{A}$ & \\
\hline & TLR9 个 & Dopaminergic neuronal loss & $\mathrm{N} / \mathrm{A}$ & \\
\hline \multirow[t]{3}{*}{ Amyotrophic lateral sclerosis } & TLR2 $\uparrow$ & Degeneration of motor neuron & N/A & $(128,129)$ \\
\hline & TLR4 $\uparrow$ & Deficiency improves motor function & N/A & \\
\hline & TLR9 个 & Deleterious & $\mathrm{N} / \mathrm{A}$ & \\
\hline \multirow[t]{2}{*}{ Stroke } & TLR2 个 & Both beneficial and deleterious & N/A & $(91,130)$ \\
\hline & TLR4 $\uparrow$ & Deleterious & Deleterious & \\
\hline
\end{tabular}

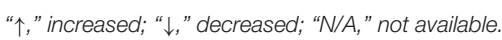


from MS patients, with PBMCs from RRMS (relapsing-remitting MS) being hypersensitive to TLR4 activation (152). Furthermore, different studies using MS knockout models have outlined the crucial role played by TLRs and their signaling proteins. For example, TLR2 (153), TLR9 (154), MyD88 (154-156) and IRF-3 (157) deficiency resulted in protective effects in neuroinflammatory models, while TLR4 (156), TLR2 (118), and TRIF (158) deficiency presented aggravating disease, indicating the complex role of TLRs in inflammatory development in MS. Recent data from an experiment by Mellanby et al. demonstrate that TLR4-induced activation of DC (dendritic cells) promotes the function of pathogenic $\mathrm{T}$ cells in EAE (experimental autoimmune encephalomyelitis) (159), a result that supports the complicated role of TLRs in EAE development.

\section{TLRs Involved in ALS}

Amyotrophic lateral sclerosis (ALS) is a devastating and chronic neurodegenerative disease, characterized by the selective upper and lower motor neuron loss, while about $20-25 \%$ of ALS cases are due to different mutations in the SOD1 gene (160). The aberrant oligomerisation of mutant SOD1 (mSOD1) proteins in beta-sheet form may be responsible for the pathogenesis and progression of ALS; it has also been demonstrated that mice lacking this gene do not develop the disease (160, 161). As well, mSOD1 has also been demonstrated in mice for an elevation of TLR1, 2, 7, and 9, and mSOD1 in microglia released more superoxide, nitrate and nitrite, resulting in severe neuronal death (Figure 2 and Table 3) (128). One study demonstrated that mSOD1 activates in microglia via a MyD88-dependent pathway, with some analyses documenting the significant effect of MyD88 in an ALS model (162). Although no significant difference is visible in the life-span of MyD88 knockout and normal mice, MyD88 knockout mice had increased activated microglia and motor neuron loss, indicative of a link between MyD88 deficiency and neurotoxicity (162). In contrast, a recent study demonstrated blocking TLR2 and 4 signaling, inhibiting microglial activation following extracellular mSOD1 administration (163). However, the chronic systemic administration of LPS aggravates disease progression and motor neuron degeneration with the elevation of TLR2 expression, suggesting a correlation between TLR2 expression and motor neuron degeneration (164). Thus, targeting TLR may attenuate neurotoxicity in ALS and potentially impact therapy; however, there is no clear evidence for a specific TLR that may mediate this effect. Therefore, the potential link between TLR signaling and neurotrophic factor secretion increment from glial cells could be a therapeutic approach in ALS.

\section{Polyphenol-Based TLR-Signaling Pathway Targeting: A Neurodegeneration Therapeutic Approach}

Polyphenols are natural resources, potentially contributing to different therapeutic conditions with their anti-inflammatory and anti-oxidant properties, as well as interrupting the TLR4signaling pathway. For example, green tea polyphenols have been examined to understand their effect on human periodontal inflammation induced by LPS at the pathogenic dose, with reported reduced TLR4 secretion and expression at both the mRNA and protein levels. That same extract was also reported to restore (150) standard hydrogen peroxide and hypochlorous acid, as well as to reduce the mRNA expression of TLR4 and IкK (165). Thus, polyphenols can decrease inflammation via TLR4 signaling pathway modulation (Figure 3 and Table 4).

Neuroinflammation leads to the progress of neurodegeneration. In this aspect, TLRs play an essential role in several CNS disorders, and different studies have reported that TLR4, among other TLRs, are a frequent contributor to neuronal death, blood-brain barrier damage, oedema and ischemic brain injury $(143,176)$. Thus, the TLR4/NF-кB-signaling pathway plays a vital role in the activation of a different inflammatory gene expressing cytokines, chemokines such as COX-2 and MMP-9, and causes cerebral inflammation, as well as leading to secondary brain injury following traumatic brain injury (176179). This upregulation of different cytokines or chemokines could also activate microglia; consequently, inflammatory cells infiltrate into the brain and may cause neuronal loss $(180,181)$. Recently, TLR4 was found to play a role in ethanol-induced inflammatory signaling. The study demonstrated that a TLR4 knockdown model abolished both MAPK and NF-кB-pathways and inflammatory mediators produced by astrocytes $(182,183)$. Also, use of quercetin, loaded into nanoparticles, improved their passage through the $\mathrm{BBB}$ and prevented $\mathrm{AD}$ progression via attenuating the TLR4-involved pathway (184). It also reduced inflammatory cytokine production by inhibiting TLR2 and 4 expression (168). Therefore, targeting TLR4 may be a particularly useful and novel strategy to treat neurodegenerative disorders.

Resveratrol, as earlier mentioned, is a potential neuroprotective and anti-inflammatory polyphenol, and under observation for the treatment of $\mathrm{AD}$, inhibits murine RAW 264.7 macrophages and microglial BV-2 cells targeted by TLR4 ligand. Additionally, resveratrol inhibits downstream phosphorylation of STAT1 and STAT3 stimulated by LPS (71). Park and Yoon reported that isoliquiritigenin, a flavonoid derivative, inhibits LPS-induced TLR4 dimerization in RAW 264.7 macrophage lines. Therefore, it inhibits NF- $\kappa \mathrm{B}$ and IRF3 activation, as well as COX-2 and inducible NO synthase expression (173). Similarly, luteolin suppressed activation of IRF3 and NF- $\mathrm{B}$ induced by TLR3 and TLR4 agonists via the TRIF-dependent pathway, resulting in decreased expression of TNF- $\alpha$ and IL- 6 in macrophages (174). These results indicate that polyphenols have the ability to modulate the TLR-pathway through TRIF-dependent signaling and result in potential attenuation of inflammatory cytokines. In a recent study, it was reported that silymarin pre-treatment significantly reduced overexpression of TLR4 in SNc induced by 6-OHDA in a PD rat model (171).

Cur (Curcumin) is a polyphenolic compound that has been used as a cooking ingredient for centuries. It has been noted for its potential in terms of anti-viral, antioxidant, antidiabetic and anti-inflammatory roles (185-187), and also with respect to its potent suppression of the TLR4-MAPK/NF-кB pathway (Figure 3). In an in vitro study, Cur was found to suppress NF- $\kappa$ B-mediated pro-inflammatory stimulation (188) and also inhibited LPS-induced IRF3 activation via MyD88 and 


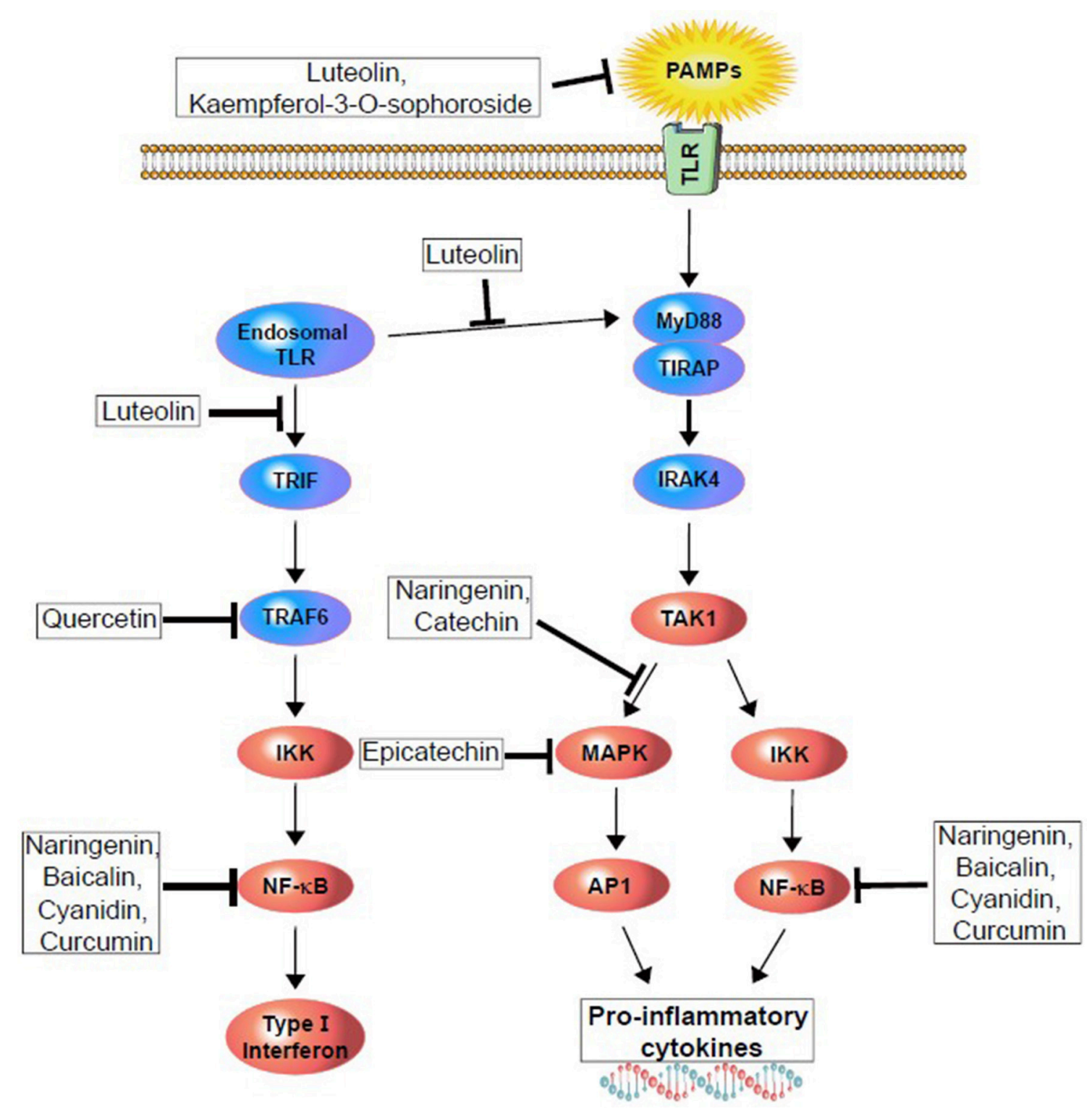

FIGURE 3 | Polyphenols modulating upstream (TLR activation) and downstream (different kinase and transcription factors) pathway of surface and endogenous TLR to reduce or demolish pro-inflammatory cytokines and type I interferon generation.

TRIF-dependent pathways. However, another study with TLR4 targeted mice showed that $100 \mathrm{mg} / \mathrm{kg}$ treatment of Cur significantly reduced TLR4-positive microglia/macrophages and other inflammatory mediators' release, which are responsible for neuronal apoptosis. These results indicate that postinjury administration of Cur decreases acute activation of microglia/macrophages and neuronal apoptosis through intervening in the TLR4/MyD88/NF- $\kappa \mathrm{B}$-signaling pathway (Table 4) $(170,187)$. Cur can cross the BBB and thus, provide pharmacological activity efficiently, as demonstrated by Yang et al. (189). A recent study showed that Cur attenuates homodimerization of TLR4, which is necessary to trigger downstream cascade pathways (190). Thus, Cur can reduce inflammatory damage through TLR4 pathway modulation, which has since been confirmed in experimental models of brain injury (191-193).

However, upon microbial invasion, MAPK signaling pathways are activated to produce inflammatory mediators via TLR response, in turn activating down-regulation of p38 and NF$\kappa \mathrm{B}$. In a study conducted by Yilma et al. naringenin was shown to inhibit TLR2 and 4 signaling (169), resulting in attenuation of pathogen-induced neuroinflammation. Moreover, EGCG and epicatechin also inhibit MAPK and NF- $\kappa$ B activation by attenuating TLR4 signaling, whereas catechin TLR2 signaling downregulates MAPK and NF-кB activation (166, 172, 175). Therefore, it reduces pro-inflammatory mediator activation 
TABLE 4 | Different active polyphenols and their pharmacological attribution through TLR-signaling intervention.

\begin{tabular}{|c|c|c|c|c|c|}
\hline $\begin{array}{l}\text { Active } \\
\text { polyphenols }\end{array}$ & $\begin{array}{l}\text { Polyphenols } \\
\text { class }\end{array}$ & TLR intervention & $\begin{array}{l}\text { Downstream signaling } \\
\text { intervention }\end{array}$ & Response & References \\
\hline EGCG & $\begin{array}{l}\text { Catechin type; } \\
\text { belongs to the } \\
\text { flavanols }\end{array}$ & $\begin{array}{l}\text { TLR4 expression } \\
\text { through } 67 \mathrm{LR}\end{array}$ & Inhibits MAPK and NF-кB & $\begin{array}{l}\text { Inhibits LPS induced activation of } \\
\text { downstream signaling and } \\
\text { consequent inflammatory responses }\end{array}$ & $(166)$ \\
\hline Resveratrol & Stilbenes & TLR4 ligand & $\begin{array}{l}\text { Inhibit downstream phosphorylation } \\
\text { of STAT1 and } 3\end{array}$ & $\begin{array}{l}\text { Reduced macrophages and microglial } \\
\text { activation }\end{array}$ & $(71)$ \\
\hline $\begin{array}{l}\text { Kaempferol-3-O- } \\
\text { sophoroside }\end{array}$ & Flavonoids & $\begin{array}{l}\text { Cell surface TLR2 } \\
\text { and } 4\end{array}$ & $\begin{array}{l}\text { Inhibit HMGB1 induced } \\
\text { proinflammatory responses }\end{array}$ & $\begin{array}{l}\text { Inhibits HMGB1-mediated } \\
\text { proinflammatory cytokine production }\end{array}$ & $(167)$ \\
\hline Quercetin & $\begin{array}{l}\text { Flavonols } \\
\text { (Flavonoids) }\end{array}$ & $\begin{array}{l}\text { TLR/NF-кB } \\
\text { signaling pathway }\end{array}$ & $\begin{array}{l}\text { Reduced IL-6 production and } \\
\text { NF-kBp65 nuclear translocation }\end{array}$ & $\begin{array}{l}\text { Downregulates inflammatory enzyme } \\
\text { production }\end{array}$ & $(168)$ \\
\hline Naringenin & $\begin{array}{l}\text { Flavanones } \\
\text { (Flavonoids) }\end{array}$ & TLR2 and 4 & MAPK pathway & $\begin{array}{l}\text { Downregulation of TNF- } \alpha, \mathrm{IL}-1 \beta, \mathrm{IL}-6 \\
\text { and other co-related inflammatory } \\
\text { cytokines }\end{array}$ & $(169)$ \\
\hline Curcumin & Curcuminoids & TLR4 & $\begin{array}{l}\text { MyD88 and NF-кB downstream } \\
\text { signaling }\end{array}$ & $\begin{array}{l}\text { Reduce activation of } \\
\text { microglia/macrophages and neuronal } \\
\text { apoptosis }\end{array}$ & $(170)$ \\
\hline Silymarin & Flavonoids & TLR4 & $\begin{array}{l}\text { Inhibit TNF- } \alpha, \text { IL- } 6 \text { and IL-1 } \beta \\
\text { production }\end{array}$ & $\begin{array}{l}\text { Attenuate deterioration of the nigral } \\
\text { degeneration during PD }\end{array}$ & $(171)$ \\
\hline Epicatechine & Flavanols & TLR4 & Inhibits MAPK and NF-кB & Reduce neuronal apoptosis & $(172)$ \\
\hline Isoliquiritigenin & $\begin{array}{l}\text { Isoflavonoids } \\
\text { (Flavonoids) }\end{array}$ & TLR4 & Inhibits IRF3 activation & $\begin{array}{l}\text { Decrease inflammatory gene } \\
\text { expression }\end{array}$ & $(173)$ \\
\hline $\begin{array}{l}\text { Soybean } \\
\text { Isoflavones }\end{array}$ & Isoflavones & TLR4 & $\begin{array}{l}\text { Inhibits NF-кB p65 expression in the } \\
\text { brain tissue }\end{array}$ & $\begin{array}{l}\text { Reduced A }(1-42) \text {, as well as } \\
\text { cytokine cascade and inflammatory } \\
\text { response and improved learning and } \\
\text { memory }\end{array}$ & (69) \\
\hline Luteolin & $\begin{array}{l}\text { Flavones } \\
\text { (Flavonoids) }\end{array}$ & TLR3 and 4 & $\begin{array}{l}\text { TBK1 kinase and IRF3 } \\
\text { phosphorylation }\end{array}$ & $\begin{array}{l}\text { Modulated TRIF-dependent } \\
\text { inflammatory responses }\end{array}$ & $(174)$ \\
\hline Catechin & $\begin{array}{l}\text { Flavanols } \\
\text { (Flavonoids) }\end{array}$ & TLR2 & $\begin{array}{l}\text { Downregulates p38MAPK and NF-кB } \\
\text { p65 }\end{array}$ & $\begin{array}{l}\text { Reduced pro-inflammatory mediators } \\
\text { and phosphorylation of their signal } \\
\text { transduction }\end{array}$ & $(175)$ \\
\hline Fisetin & Flavonoids & TLR4 & $\begin{array}{l}\text { Suppress NF-кB activation and } \\
\text { JNK/JUN phosphorylation }\end{array}$ & Neuroprotection in cerebral ischemia & $(61)$ \\
\hline Baicalin & Flavonoids & TLR2 and 4 & $\begin{array}{l}\text { Reduce the expression of NF-кB and } \\
\text { serum content of TNF- } \alpha \text { and } \mathrm{IL}-1 \beta\end{array}$ & Neuroprotection in cerebral ischemia & $(75)$ \\
\hline
\end{tabular}

and phosphorylation, as well as consequent neurodegeneration. A recent study reports that epigallocatechin gallate (EGCG) treatment prevents neurological pain via suppressing TLR4 cascades in a neuropathic rat model (194). Moreover, EGCG is one of the potent flavonoids found in green tea and is reputed for its ability to provide neuroprotection $(195,196)$. In an LPS-induced neuroinflammation mouse model, neurogenesis significantly decreased neuronal stem cell differentiation and proliferation. Additionally, microglial cells accumulated to initiate the LR4/NF- $\mathrm{B}$-signaling pathway in the hippocampus of mice. EGCG treatment showed an overall beneficial effect in this study with neurogenesis by inhibiting the TLR4/NF- $\kappa \mathrm{B}$-signaling pathway (197).

TLRs are critical elements of the innate immune system, and recent studies demonstrated their involvement in different brain injury-derived neurodegeneration processes. However, neuroinflammation plays an important role and leads to the development of neurodegenerative diseases, such as $\mathrm{AD}$, $\mathrm{PD}$, or MS. Indeed, several inflammatory markers, such as chemokines, cytokines or proteins in acute phase are upregulated and lead to inflammation, and these markers also prevail in neurodegenerative diseases, including AD (198-200). Additionally, TLR4 signaling pathways are involved and control these markers' upregulation. Thus, targeting TLR4 may represent an important therapeutic strategy to prevent neurodegenerative disorders mediated by different inflammatory markers $(18,182)$.

\section{CONCLUDING REMARKS AND FUTURE ASPECTS}

Neurodegeneration is a pathological condition that includes the activation of different neuronal inflammatory cytokines and chemokines cascade, release of endotoxin and autoimmune disturbances and the overproduction of mitochondrial ROS. Here, a separate context was discussed to correlate the significance of NF- $\kappa \mathrm{B}$ in the CNS and its regulation through TLR members. Further, recent approaches using polyphenols in the treatment of neurodegeneration were also discussed. Several polyphenolic compounds have been found to show promise for attenuating neurodegenerative disorders via involving 
interrelated mechanisms. However, they more likely target TLR4linked pathway modulation to reduce inflammatory progression. There is growing evidence for the involvement of TLR4 in the etiology of different neuropsychiatric diseases; however, the source of TLR4 activation is yet to be determined. There appears to be two major pathways involved in TLR4 activation: either Gram-negative gut Enterobacter translocation or excessive production and release of ROS due to anonymous infection. In contrast, there are insufficient data regarding TLR4 dependent or independent cytokine effects and polyphenols' role on them in the progression of neurodegenerative diseases, while abundant investigation has been made regarding the role of cytokines in the pathogenesis of the same disorders.

Although neurodegeneration is a growing threat, there are only a few clinically relevant therapeutics for ND available, and they are for symptomatic treatment only. In this position with pathological concern and limited treatments, alternative and preventive therapeutics are rational to control the occurrence and progression of NDs. Some of them are under clinical investigation for therapeutic efficacy in neuropathological conditions; however, many more are expected to be tested in clinical trials for their in vitro and in vivo roles. Indeed, neurodegenerative diseases are complicated cases and involve several signaling cascades, but the role of $A \beta$-plaque aggregation and production of inflammatory cytokines and chemokines is also essential. In this case, several polyphenols have been shown to significantly attenuate $A \beta$-plaques and inflammatory cytokine and chemokine production via intervening different signaling pathways, explicitly targeting the TLR4/NF- $\mathrm{B}$-signaling pathway in $\mathrm{AD}, \mathrm{PD}, \mathrm{MS}$, or stroke. Engagement of TLR along with another innate immune member, the NLR family, is also an important factor to release cytokines and to form a multiprotein inflammatory complex, the inflammasome. This emerging view is also important with respect to host response to pathogenic stimuli, and mature IL- $1 \beta$ release is a suitable example of this process, which aggravates the neurodegeneration. Therefore, future work should also focus on this area to determine precise

\section{REFERENCES}

1. Manach SA, Morand C, Rémésy C, Jiménez L. Polyphenols: food sources and bioavailability. Am J Clin Nutr. (2004) 79:727-47. doi: 10.1093/ajcn/79.5.727

2. Marrugat JC, Fitó M-I, Schröder M, Miró-Casas H, Gimeno E, López-Sabater E. Effects of differing phenolic content in dietary olive oils on lipids and LDL oxidation. Eur J Nutr. (2004) 43:140-7. doi: 10.1007/s00394-004-0452-8

3. Scalbert A, Johnson IT, Saltmarsh M. Polyphenols: antioxidants and beyond. Am J Clin Nutr. (2005) 81:215S-217S. doi: 10.1093/ajcn/81.1.215S

4. D’Archivio M, Filesi C, Di Benedetto R, Gargiulo R, Giovannini C, Masella R. Polyphenols, dietary sources and bioavailability. Annal Istit Superiore Sanita. (2007) 43:348-61.

5. Abbas M, Saeed F, Anjum FM, Afzaal M, Tufail T, Ishtiaq A, et al. Natural polyphenols: an overview. Int J Food Properties. (2017) 20:1689-99. doi: 10.1080/10942912.2016.1220393

6. Pandey KB, Rizvi SI, Plant polyphenols as dietary antioxidants in human health and disease. Oxid Med Cell Longev. (2009) 2:270-8. doi: 10.4161/oxim.2.5.9498

7. Ka J. Cell death mechanisms in neurodegeneration. J Cell Mol Med. (2001) 5:1-17. doi: 10.1111/j.1582-4934.2001.tb00134.x signaling pathways and mechanisms, leading to comprehension of disease phenotypes and searches for effective therapeutics.

Based on a number of recent investigations, it is clear that polyphenols are promising, and their approaches involve TLR4 modulation to control NDs. Polyphenols have been found to reduce mRNA expression of TLR4 and ІкK, while enhancing the MyD88-dependent TLR4/NF$\kappa \mathrm{B}$-signaling pathway. However, this article attempted to describe the involvement of TLR4 in neurodegeneration and the role played by polyphenols via intervening in this pathway. Indeed, while polyphenols' action against innate immunity may be beneficial, the innate immune response is necessary under different CNS pathological conditions, where TLR4 activation can be neuroprotective. Although TLR4 removes $A \beta$-plaques by microglia via controlling phagocytes, TLR4 cytotoxicity has also been found to be significant in several studies. Therefore, it is necessary to elucidate TLR4s' complex signaling in the brain to gain control over inflammation-induced NDs. Targeting TLR4 would provide a highly suitable treatment approach, with significant implications in the designing of novel therapeutics for these particular diseases.

\section{AUTHOR CONTRIBUTIONS}

SA, D-KC, MJ, and I-SK conceptualized and designed the study. D-KC also supervised and corresponded. SA reviewed the literature, wrote the manuscript and compiled tables. SA and I-SK drew the figures. MEH and JK helped in revising the paper. All authors read and approved the final manuscript.

\section{FUNDING}

Basic Science Research Program supported this research through the National Research Foundation of Korea (NRF) funded by the Ministry of Science and ICT (Grant No. 2017R1A2A2A07001035).
8. Amor SPF, Baker D, Van Der Valk P. Inflammation in neurodegenerative diseases. Immunology. (2010) 129:154-69. doi: 10.1111/j.1365-2567.2009.03225.x

9. Mn C. Chlorogenic acids and other cinnamates. Nature, occurence, dietary burden, absorption and metabolism. J Sci Food Agric. (2000) 80:103343. doi: 10.1002/(SICI)1097-0010(20000515)80:7<1033::AID-JSFA595>3. $0 . \mathrm{CO} ; 2-\mathrm{T}$

10. Pandey Kb RS. Protective effect of resveratrol on markers of oxidative stress in human erythrocytes subjected to in vitro oxidative insult. Phytother Res. (2010) 24:S11-14. doi: 10.1002/ptr.2853

11. Choi DY, Lee YJ, Hong JT, Lee HJ. Antioxidant properties of natural polyphenols and their therapeutic potentials for Alzheimer's disease. Brain Res Bull. (2012) 87:144-53. doi: 10.1016/j.brainresbull.2011.11.014

12. Hanisch UK, Kettenmann H. Microglia: active sensor and versatile effectorcells in the normal and pathologic brain. Nat Neurosci. (2007) 10:1387-94. doi: 10.1038/nn1997

13. Meng Q, Velalar CN, Ruan R. Regulating the age-related oxidative damage, mitochondrial integrity, and antioxidative enzyme activity in Fischer 344 rats by supplementation of the antioxidant epigallocatechin-3-gallate. Rejuvenation Res. (2008) 11:649-60. doi: 10.1089/rej.2007.0645 
14. Wang HC, Brumaghim JL. Polyphenol compounds as antioxidants for disease prevention: reactive oxygen species scavenging, enzyme regulation, and metal chelation mechanisms in E. coli and human cells. In: Andreescu S, Hepel M, editors. Oxidative Stress: Diagnostics, Prevention, and Therapy American Chemical Society. Washington, DC: American Chemical Society (2011). p. 99-175. doi: 10.1021/bk-2011-1083.ch005

15. Jayasena PA, Smythe G, Braidy N, Münch G, Sachdev P. The role of polyphenols in the modulation of sirtuins and other pathways involved in Alzheimer's disease. Ageing Res Rev. (2013) 12:867-83. doi: 10.1016/j.arr.2013.06.003

16. Hailer NP. Immunosuppression after traumatic or ischemic CNS damage: itis neuroprotective and illuminates the role of microglial cells. Prog Neurobiol. (2008) 84:211-33. doi: 10.1016/j.pneurobio.2007.12.001

17. Mccoy MK, Tansey MG. TNF signaling inhibition in the CNS: implicationsfor normal brain function and neurodegenerative disease. J Neuroinflamm. (2008) 5:45. doi: 10.1186/1742-2094-5-45

18. Rahimifard M, Maqbool F, Moeini-Nodeh S, Niaz K, Abdollahi M, Braidy $\mathrm{N}$, et al. Targeting the TLR4 signaling pathway by polyphenols: a novel therapeutic strategy for neuroinflammation. Ageing Res Rev. (2017) 36:11-9. doi: 10.1016/j.arr.2017.02.004

19. Tresserra-Rimbau A, Lamuela-Raventos RM, Moreno JJ. Polyphenols, food and pharma. Current knowledge and directions for future research. Biochem Pharmacol. (2018) 156:186-95. doi: 10.1016/j.bcp.2018.07.050

20. Bravo L. Polyphenols: chemistry, dietary sources, metabolism, and nutritional significance. Nutr Rev. (1998) 56:317-33. doi: 10.1111/j.1753-4887.1998.tb01670.x

21. Storniolo CE, Quifer-Rada P, Lamuela-Raventos RM, Moreno JJ. Piceid presents antiproliferative effects in intestinal epithelial Caco-2 cells, effects unrelated to resveratrol release. Food Funct. (2014) 5:2137-44. doi: 10.1039/C4FO00305E

22. Pandareesh MD, Mythri RB, Srinivas Bharath MM. Bioavailability of dietary polyphenols: factors contributing to their clinical application in CNS diseases. Neurochem Int. (2015) 89:198-208. doi: 10.1016/j.neuint.2015.07.003

23. Walle T. Absorption and metabolism of flavonoids. Free Radic Biol Med. (2004) 36:829-37. doi: 10.1016/j.freeradbiomed.2004.01.002

24. Pan MH, Huang TM, Lin JK. Biotransformation of curcumin through reduction and glucuronidation in mice. Drug Metab Dispos. (1999) 27:48694.

25. Garcea G, Jones DJL, Singh R, Dennison AR, Farmer PB, Sharma RA, et al. Detection of curcumin and its metabolites in hepatic tissue and portal blood of patients following oral administration. Br J Cancer. (2004) 90:1011-5. doi: 10.1038/sj.bjc.6601623

26. Saiko P, Szakmary A, Jaeger W, Szekeres T. Resveratrol and its analogs: defense against cancer, coronary disease and neurodegenerative maladies or just a fad? Mutat Res. (2008) 658:68-94. doi: 10.1016/j.mrrev.2007.08.004

27. Ritz MF, Ratajczak P, Curin Y, Cam E, Mendelowitsch A, Pinet F, et al. Chronic treatment with red wine polyphenol compounds mediates neuroprotection in a rat model of ischemic cerebral stroke. J Nutr. (2008) 138:519-25. doi: $10.1093 / \mathrm{jn} / 138.3 .519$

28. Zhu A, Wang X, Guo Z. Study of tea polyphenol as a reversal agent for carcinoma cell lines' multidrug resistance (study of TP as a MDR reversal agent). Nucl Med Biol. (2001) 28:735-40. doi: 10.1016/S0969-8051(00)90202-6

29. Mei Y, Qian F, Wei D, Liu J. Reversal of cancer multidrug resistance by green tea polyphenols. J Pharm Pharmacol. (2004) 56:1307-14. doi: $10.1211 / 0022357044364$

30. Kitagawa S. Inhibitory effects of polyphenols on p-glycoprotein-mediated transport. Biol Pharm Bull. (2006) 29:1-6. doi: 10.1248/bpb.29.1

31. Tsai TH. Determination of naringin in rat blood, brain, liver, and bile using microdialysis and its interaction with cyclosporin a, a p-glycoprotein modulator. J Agric Food Chem. (2002) 50:6669-74. doi: 10.1021/jf0 20603p

32. Scheepens A, Tan K, Paxton JW. Improving the oral bioavailability of beneficial polyphenols through designed synergies. Genes Nutr. (2010) 5:7587. doi: 10.1007/s12263-009-0148-z

33. Ho L, Ferruzzi MG, Janle EM, Wang J, Gong B, Chen TY, et al. Identification of brain-targeted bioactive dietary quercetin-3-O-glucuronide as a novel intervention for Alzheimer's disease. Faseb J. (2013) 27:769-81. doi: $10.1096 /$ fj.12-212118
34. Ray B, Bisht S, Maitra A, Maitra A, Lahiri DK. Neuroprotective and neurorescue effects of a novel polymeric nanoparticle formulation of curcumin (NanoCurc) in the neuronal cell culture and animal model: implications for Alzheimer's disease. J Alzheimers Dis. (2011) 23:61-77. doi: 10.3233/JAD-2010-101374

35. Suresh D, Srinivasan K. Tissue distribution and elimination of capsaicin, piperine and curcumin following oral intake in rats. Ind J Med Res. (2010) 131:682-91.

36. Chao J, Yu MS, Ho YS, Wang M, Chang RC. Dietary oxyresveratrol prevents parkinsonian mimetic 6-hydroxydopamine neurotoxicity. Free Radic Biol Med. (2008) 45:1019-26. doi: 10.1016/j.freeradbiomed.2008.07.002

37. Chao J, Lau WK, Huie MJ, Ho YS, Yu MS, Lai CS, et al. A pro-drug of the green tea polyphenol (-)-epigallocatechin-3-gallate (EGCG) prevents differentiated SH-SY5Y cells from toxicity induced by 6-hydroxydopamine. Neurosci Lett. (2010) 469:360-4. doi: 10.1016/j.neulet.2009.12.028

38. Wang J, Ferruzzi MG, Ho L, Blount J, Janle EM, Gong B, et al. Brain-targeted proanthocyandinin metabolites for Alzheimer's disease treatment. J Neurosci. (2012) 32:5144-50. doi: 10.1523/JNEUROSCI.6437-11.2012

39. Qin XY, Cheng Y, Yu LC. Potential protection of green tea polyphenols against intracellular amyloid beta induced toxicity on primary cultured prefrontal cortical neurons of rats. Neurosci Lett. (2012) 513:170-3. doi: 10.1016/j.neulet.2012.02.029

40. Thomas P, Wang YJ, Zhong JH, Kosaraju S, O'Callaghan NJ, Zhou XF, et al. Grape seed polyphenols and curcumin reduce genomic instability events in a transgenicmousemodel forAlzheimer's disease. Mutat Res Fundamental Mol Mech Mutagenesis. (2009) 661:25-34. doi: 10.1016/j.mrfmmm.2008. 10.016

41. Wang T, Gu J, Wu PF, Wang F, Xiong Z, Yang YJ, et al. Protection by tetrahydroxystilbene glucoside against cerebral ischemia: involvement of JNK, SIRT1, and NF-kappaB pathways and inhibition of intracellular ROS/RNS generation. Free Rad Biol Med. (2009) 47:229-40. doi: 10.1016/j.freeradbiomed.2009.02.027

42. Feng Y, Wang X, Yang SG, Wang YJ, Zhang X, Du XT, et al. Resveratrol inhibits betaamyloid oligomeric cytotoxicity but does not prevent oligomer formation. NeuroToxicol. (2009) 30:986-95. doi: 10.1016/j.neuro.2009.08.013

43. Liu P, Kemper LJ, Wang J, Zahs KR, Ashe KH, Pasinetti GM. Grape seed polyphenolic extract specifically decreases A. J Alzheimer's Dis. (2011) 26:657-66. doi: 10.3233/JAD-2011-110383

44. Huang TC, Lu KT, Wo YY, Wu YJ, Yang YL. Resveratrol protects rats from A. PLoS ONE. (2011) 6:e029102. doi: 10.1371/journal.pone.0029102

45. Ksiezak-Reding H, Ho L, Santa-Maria I, Diaz-Ruiz C, Wang J, Pasinetti GM. Ultrastructural alterations of Alzheimer's disease paired helical filaments by grape seed-derived polyphenols. Neurobiol Aging. (2012) 33:1427-39. doi: 10.1016/j.neurobiolaging.2010.11.006

46. Rupasinghe KSB, Vasantha Rupasinghet HP. Polyphenols: multipotent therapeutic agents in neurodegenerative diseases. Oxidative Med Cell Long. (2013) 2013:18. doi: 10.1155/2013/891748

47. Devi L, Ohno M. 7,8-Dihydroxyflavone, a Small-Molecule TrkB agonist, reverses memory deficits and BACE1 elevation in a mouse model of alzheimer's Disease. Neuropsychopharmacology. (2011) 37:434. doi: 10.1038/npp.2011.191

48. Wang SW, Wang YJ, Su YJ, Zhou WW, Yang SG, Zhang R, et al. Rutin inhibits $\beta$-amyloid aggregation and cytotoxicity, attenuates oxidative stress, and decreases the production of nitric oxide and proinflammatory cytokines. Neurotoxicology. (2012) 33:482-90. doi: 10.1016/j.neuro.2012.03.003

49. Magalingam KB, Radhakrishnan AK, Haleagrahara N. Protective Mechanisms of Flavonoids in Parkinson's Disease. Oxid Med Cell Longev. (2015) 2015:314560. doi: 10.1155/2015/314560

50. Ha SK, Lee P, Park JA, Oh HR, Lee SY, Park JH, et al. Apigenin inhibits the production of NO and PGE2 in microglia and inhibits neuronal cell death in a middle cerebral artery occlusion-induced focal ischemia mice model. Neurochem Int. (2008) 52:878-86. doi: 10.1016/j.neuint. 2007.10.005

51. Chen HQ, Jin ZY, Wang XJ, Xu XM, Deng L, Zhao JW. Luteolin protects dopaminergic neurons from inflammation-induced injury through inhibition of microglial activation. Neurosci Lett. (2008) 448:175-9. doi: 10.1016/j.neulet.2008.10.046

52. Filomeni G, Graziani I, De Zio D, Dini L, Centonze D, Rotilio G, et al. Neuroprotection of kaempferol by autophagy in 
models of rotenone-mediated acute toxicity: possible implications for Parkinson's disease. Neurobiol Aging. (2012) 33:767-85. doi: 10.1016/j.neurobiolaging.2010.05.021

53. Zhang K, Ma Z, Wang J, Xie A, Xie J. Myricetin attenuated MPP(+)induced cytotoxicity by anti-oxidation and inhibition of MKK4 and JNK activation in MES23.5 cells. Neuropharmacology. (2011) 61:329-35. doi: 10.1016/j.neuropharm.2011.04.021

54. Karuppagounder SS, Madathil SK, Pandey M, Haobam R, Rajamma U, Mohanakumar KP. Quercetin up-regulates mitochondrial complexI activity to protect against programmed cell death in rotenone model of Parkinson's disease in rats. Neuroscience. (2013) 236:136-48. doi: 10.1016/j.neuroscience.2013.01.032

55. Teixeira MD, Souza CM, Menezes AP, Carmo MR, Fonteles AA, Gurgel JP, et al. Catechin attenuates behavioral neurotoxicity induced by 6-OHDA in rats. Pharmacol Biochem Behav. (2013) 110:1-7. doi: 10.1016/j.pbb.2013.05.012

56. Lou $H$, Jing $X$, Wei $X$, Shi $H$, Ren $D$, Zhang $X$. Naringenin protects against 6-OHDA-induced neurotoxicity via activation of the Nrf2/ARE signaling pathway. Neuropharmacology. (2014) 79:380-8. doi: 10.1016/j.neuropharm.2013.11.026

57. Anandhan A, Tamilselvam K, Radhiga T, Rao S, Essa MM, Manivasagam T. Theaflavin, a black tea polyphenol, protects nigral dopaminergic neurons against chronic MPTP/probenecid induced Parkinson's disease. Brain Res. (2012) 1433:104-13. doi: 10.1016/j.brainres.2011.11.021

58. Hou YC, Liou KT, Chern CM, Wang YH, Liao JF, Chang S, et al. Preventive effect of silymarin in cerebral ischemia-reperfusion-induced brain injury in rats possibly through impairing NF-kappaB and STAT-1 activation. Phytomedicine. (2010) 17:963-73. doi: 10.1016/j.phymed.2010.03.012

59. Zhang F-X, Xu R-S. Juglanin ameliorates LPS-induced neuroinflammation in animal models of Parkinson's disease and cell culture via inactivating TLR4/NF- $\mathrm{KB}$ pathway. Biomed Pharmacother. (2018) 97:1011-9. doi: 10.1016/j.biopha.2017.08.132

60. Yen TL, Hsu CK, Lu WJ, Hsieh CY, Hsiao G, Chou DS, et al. Neuroprotective effects of xanthohumol, a prenylated flavonoid from hops (Humulus lupulus), in ischemic stroke of rats. J Agric Food Chem. (2012) 60:1937-44. doi: 10.1021/jf204909p

61. Gelderblom M, Leypoldt F, Lewerenz J, Birkenmayer G, Orozco D, Ludewig P, et al. The flavonoid fisetin attenuates postischemic immune cell infiltration, activation and infarct size after transient cerebral middle artery occlusion in mice. J Cereb Blood Flow Metab. (2012) 32:835-43. doi: $10.1038 / j \mathrm{cbfm} .2011 .189$

62. Kim HY, Lee SM. Ferulic acid attenuates ischemia/reperfusion-induced hepatocyte apoptosis via inhibition of JNK activation. Eur J Pharm Sci. (2012) 45:708-15. doi: 10.1016/j.ejps.2012.01.010

63. Ho DJ, Calingasan NY, Wille E, Dumont M, Beal MF. Resveratrol protects against peripheral deficits in amouse model of Huntington's disease. Exp Neurol. (2010) 225:74-84, doi: 10.1016/j.expneurol.2010.05.006

64. Tai K-K, Truong DD. (-)-Epigallocatechin-3-gallate (EGCG), a green tea polyphenol, reduces dichlorodiphenyl-trichloroethane (DDT)-induced cell death in dopaminergic SHSY-5Y cells. Neurosci Lett. (2010) 482:183-7. doi: 10.1016/j.neulet.2010.06.018

65. Vauzour D, Corona G, Spencer JP. Caffeic acid, tyrosol and p-coumaric acid are potent inhibitors of 5-S-cysteinyl-dopamine induced neurotoxicity. Arch Biochem Biophys. (2010) 501:106-11. doi: 10.1016/j.abb.2010.03.016

66. Kim HG, Ju MS, Shim JS, Kim MC, Lee SH, Huh Y, et al. Mulberry fruit protects dopaminergic neurons in toxin-induced Parkinson's disease models. Br J Nutr. (2010) 104:8-16. doi: 10.1017/S0007114510000218

67. Fonseca-Kelly Z, Nassrallah M, Uribe J, Khan RS, Dine K, Dutt M, et al. Resveratrol neuroprotection in a chronic mouse model of multiple sclerosis. Front Neurol. (2012) 3:84. doi: 10.3389/fneur.2012.00084

68. Paris D, Mathura V, Ait-Ghezala G, Beaulieu-Abdelahad D, Patel $\mathrm{N}$, Bachmeier $\mathrm{C}$, et al. Flavonoids lower Alzheimer's $A \beta$ production via an NFKB dependent mechanism. Bioinformation. (2011) 6:229-36. doi: 10.6026/97320630006229

69. Ding BJ, Ma WW, He LL, Zhou X, Yuan LH, Yu HL, et al. Soybean isoflavone alleviates beta-amyloid 1-42 induced inflammatory response to improve learning and memory ability by down regulation of Toll-like receptor 4 expression and nuclear factor-kappaB activity in rats. Int J Dev Neurosci. (2011) 29:537-42. doi: 10.1016/j.ijdevneu.2011.04.002
70. Xue X, Qu XJ, Yang Y, Sheng XH, Cheng F, Jiang EN, et al. Baicalin attenuates focal cerebral ischemic reperfusion injury through inhibition of nuclear factor kappaB p65 activation. Biochem Biophys Res Commun. (2010) 403:398-404. doi: 10.1016/j.bbrc.2010.11.042

71. Capiralla H, Vingtdeux V, Zhao H, Sankowski R, Al-Abed Y, Davies P, et al. Resveratrol mitigates lipopolysaccharide- and Abeta-mediated microglial inflammation by inhibiting the TLR4/NF-kappaB/STAT signaling cascade. $J$ Neurochem. (2012) 120:461-72. doi: 10.1111/j.1471-4159.2011.07594.x

72. Zhang W, Potrovita I, Tarabin V, Herrmann O, Beer V, Weih F, et al. Neuronal activation of NF-kappaB contributes to cell death in cerebral ischemia. J Cereb Blood Flow Metab. (2005) 25:30-40. doi: $10.1038 /$ sj.jcbfm. 9600004

73. Chen X, Hu W, Lu X, Jiang B, Wang J, Zhang W, et al. Mechanism of 2,3,4,5-Tetrahydroxystilbene 2-O-beta-D-glucoside-induced upregulation of glutamate transporter 1 protein expression in mouse primary astrocytes. Pharmacology. (2017) 99:153-9. doi: 10.1159/000452672

74. Patir H, Sarada SK, Singh S, Mathew T, Singh B, Bansal A. Quercetin as a prophylactic measure against high altitude cerebral edema. Free Radic Biol Med. (2012) 53:659-68. doi: 10.1016/j.freeradbiomed.2012.06.010

75. Tu XK, Yang WZ, Shi SS, Chen Y, Wang CH, Chen CM, et al. Baicalin inhibits TLR2/4 signaling pathway in rat brain following permanent cerebral ischemia. Inflammation. (2011) 34:463-70. doi: 10.1007/s10753-0109254-8

76. Ashafaq M, Raza SS, Khan MM, Ahmad A, Javed H, Ahmad ME, et al. Catechin hydrate ameliorates redox imbalance and limits inflammatory response in focal cerebral ischemia. Neurochem Res. (2012) 37:1747-60. doi: 10.1007/s11064-012-0786-1

77. Shin BY, Jin SH, Cho IJ, Ki SH. Nrf2-ARE pathway regulates induction of Sestrin-2 expression. Free Radic Biol Med. (2012) 53:834-41. doi: 10.1016/j.freeradbiomed.2012.06.026

78. Ren J, Fan C, Chen N, Huang J, Yang Q. Resveratrol pretreatment attenuates cerebral ischemic injury by upregulating expression of transcription factor Nrf2 and HO-1 in rats. Neurochem Res. (2011) 36:2352-62. doi: $10.1007 / \mathrm{s} 11064-011-0561-8$

79. Shah ZA, Li RC, Ahmad AS, Kensler TW, Yamamoto M, Biswal S, et al. The flavanol (-)-epicatechin prevents stroke damage through the Nrf2/HO1 pathway. J Cereb Blood Flow Metab. (2010) 30:1951-61. doi: $10.1038 / \mathrm{jcbfm} .2010 .53$

80. Wright SD. Toll, a new piece in the puzzle of innate immunity. J Exp Med. (1999) 189:605-9. doi: 10.1084/jem.189.4.605

81. Medzhitov R, Janeway CJr. Innate immune recognition: mechanisms and pathways. Immunol Rev. (2000) 173:89-97. doi: 10.1034/j.1600-065X.2000.917309.x

82. Qureshi S, Medzhitov R. Toll-like receptors and their role in experimental models of microbial infection. Genes Immun. (2003) 4:87-94. doi: $10.1038 /$ sj.gene.6363937

83. Kaisho T, Akira S. Pleiotropic function of Toll-like receptors. Microbes Infect. (2004) 6:1388-94. doi: 10.1016/j.micinf.2004.08.019

84. Takeuchi O, Akira S. Pattern recognition receptors and inflammation. Cell. (2010) 140:805-20. doi: 10.1016/j.cell.2010.01.022

85. Mckimmie CS, Fazakerley JK. In response to pathogens, glial cells dynamically and differentially regulate Toll-like receptor gene expression. $J$ Neuroimmunol. (2005) 169:116-25. doi: 10.1016/j.jneuroim.2005.08.006

86. Hanke ML, Kielian T. Toll-like receptors in health and disease in the brain: mechanisms and therapeutic potential. Clin Sci. (2011) 121:367-87. doi: $10.1042 / C S 20110164$

87. Leow-Dyke S, Allen C, Denes A, Nilsson O, Maysami S, Bowie AG, et al. Neuronal toll-like receptor 4 signaling induces brain endothelial activation and neutrophil transmigration in vitro. J Neuroinflammation. (2012) 9:230. doi: 10.1186/1742-2094-9-230

88. Shen Y, Qin H, Chen J, Mou L, He Y, Yan Y, et al. Postnatal activation of TLR4 in astrocytes promotes excitatory synaptogenesis in hippocampal neurons. $J$ Cell Biol. (2016) 215:719-34. doi: 10.1083/jcb.201605046

89. Prehaud C, Megret F, Lafage M, Lafon M. Virus infection switches TLR-3positive human neurons to become strong producers of beta interferon. $J$ Virol. (2005) 79:12893-904. doi: 10.1128/JVI.79.20.12893-12904.2005

90. Tang SC, Arumugam TV, Xu X, Cheng A, Mughal MR, Jo DG. Pivotal role for neuronal Toll-like receptors in ischemic brain injury 
and functional deficits. Proc Natl Acad Sci USA. (2007) 104:13798-803. doi: 10.1073/pnas.0702553104

91. Okun E, Griffioen KJ, Lathia JD, Tang SC, Mattson MP, Arumugam TV. Toll-like receptors in neurodegeneration. Brain Res Rev. (2009) 59:278-92. doi: 10.1016/j.brainresrev.2008.09.001

92. Mishra BB, Gundra UM, Teale JM. Expression and distribution of Tolllike receptors $11-13$ in the brain during murine neurocysticercosis. $J$ Neuroinflammation. (2008) 5:53. doi: 10.1186/1742-2094-5-53

93. Wadachi R, Hargreaves KM. Trigeminal nociceptors express TLR-4 and CD14: a mechanism for pain due to infection. J Dent Res. (2006) 85:49-53. doi: $10.1177 / 154405910608500108$

94. Cameron JS, Alexopoulou L, Sloane JA, Dibernardo AB, Ma Y, Kosaras B, et al. Toll-like receptor 3 is a potent negative regulator of axonal growth in mammals. J Neurosci. (2007) 27:13033-41. doi: 10.1523/JNEUROSCI.4290-06.2007

95. Arancibia SA, Beltran CJ, Aguirre IM, Silva P, Peralta AL, Malinarich F, et al. Toll-like receptors are key participants in innate immune responses. Biol Res. (2007) 40:97-112. doi: 10.4067/S0716-976020070002 00001

96. Sarkar SN, Peters KL, Elco CP, Sakamoto S, Pal S, Sen GC. Novel roles of TLR3 tyrosine phosphorylation and PI3 kinase in double-stranded RNA signaling. Nat Struct Mol Biol. (2004) 11:1060-7. doi: 10.1038/ nsmb847

97. Rolls A, Shechter R, London A, Ziv Y, Ronen A, Levy R, et al. Toll-like receptors modulate adult hippocampal neurogenesis. Nat Cell Biol. (2007) 9:1081-8. doi: $10.1038 / \mathrm{ncb} 1629$

98. Jung DY, Lee H, Jung BY, Ock J, Lee MS, Lee WH, et al. TLR4, but not TLR2, signals autoregulatory apoptosis of cultured microglia: a critical role of IFN-beta as a decision maker. J Immunol. (2005) 174:6467-76. doi: 10.4049/jimmunol.174.10.6467

99. Meylan E, Burns K, Hofmann K, Blancheteau V, Martinon F, Kelliher M, et al. RIP1 is an essential mediator of Toll-like receptor 3-induced NF-kappa B activation. Nat Immunol. (2004) 5:503-7. doi: 10.1038/ni1061

100. Becker CE1, O'Neill LA. Inflammasomes in inflammatory disorders: the role of TLRs and their interactions with NLRs. Semin Immunopathol. (2007) 29:239-48. doi: 10.1007/s00281-007-0081-4

101. Babcock AA, Wirenfeldt M, Holm T, Nielsen HH, Dissing-Olesen L, ToftHansen $\mathrm{H}$, et al. Toll-like receptor 2 signaling in response to brain injury: an innate bridge to neuroinflammation. J Neurosci. (2006) 26:12826-37. doi: 10.1523/JNEUROSCI.4937-05.2006

102. Park C, Cho IH, Kim D, Jo EK, Choi SY, Oh SB, et al. Toll-like receptor 2 contributes to glial cell activation and heme oxygenase-1 expression in traumatic brain injury. Neurosci Lett. (2008) 431:123-8. doi: $10.1016 /$ j.neulet.2007.11.057

103. Zhou ML, Shi JX, Hang CH, Zhang FF, Gao J, Yin HX. Expression of Toll-like receptor 4 in the brain in a rabbit experimental subarachnoid haemorrhage model. Inflamm Res. (2007) 56:93-7. doi: 10.1007/s00011-006-6035-9

104. Zhou ML, Wu W, Ding YS, Zhang FF, Hang CH, Wang HD, et al. Expression of Toll-like receptor 4 in the basilar artery after experimental subarachnoid hemorrhage in rabbits: a preliminary study. Brain Res. (2007) 1173:110-6. doi: 10.1016/j.brainres.2007.07.059

105. Ma CX, Yin WN, Cai BW, Wu J, Wang JY, He M, et al. Toll-like receptor 4/nuclear factor-kappa B signaling detected in brain after early subarachnoid hemorrhage. Chin Med J. (2009) 122:1575-81.

106. Teng W, Wang L, Xue W, Guan C. Activation of TLR4-mediated NFkappaB signaling in hemorrhagic brain in rats. Mediators Inflamm. (2009) 2009:473276. doi: 10.1155/2009/473276

107. Kong Y, Le Y. Toll-like receptors in inflammation of the central nervous system. Int Immunopharmacol. (2011) 11:1407-14. doi: 10.1016/j.intimp.2011.04.025

108. Trudler D, Farfara D, Frenkel D. Toll-like receptors expression and signaling in glia cells in neuro-amyloidogenic diseases: towards future therapeutic application. Mediat Inflamm. (2010) 2010:12. doi: 10.1155/20 $10 / 497987$

109. Carpentier A, Laigle-Donadey F, Zohar S, Capelle L, Behin A, Tibi A, et al. Phase 1 trial of a CpG oligodeoxynucleotide for patients with recurrent glioblastoma. Neuro Oncol. (2006) 8:60-6. doi: 10.1215/S15228517 05000475
110. Meng Y, Kujas M, Marie Y, Paris S, Thillet J, Delattre JY, et al. Expression of TLR9 within human glioblastoma. J Neurooncol. (2008) 88:19-25. doi: 10.1007/s11060-008-9536-2

111. Carpentier A, Metellus P, Ursu R, Zohar S, Lafitte F, Barrié M, et al. Intracerebral administration of $\mathrm{CpG}$ oligonucleotide for patients with recurrent glioblastoma: a phase II study. Neuro Oncol. (2010) 12:401-8. doi: 10.1093/neuonc/nop047

112. Lotz M, Ebert S, Esselmann H, Iliev AI, Prinz M, Wiazewicz N, et al. Amyloid beta peptide 1-40 enhances the action of Toll-like receptor-2 and -4 agonists but antagonizes Toll-like receptor-9-induced inflammation in primary mouse microglial cell cultures. J Neurochem. (2005) 94:289-98. doi: 10.1111/j.1471-4159.2005.03188.x

113. Minoretti P, Gazzaruso C, Vito CD, Emanuele E, Bianchi M, Coen E, et al. Effect of the functional toll-like receptor 4 Asp299Gly polymorphism on susceptibility to late-onset Alzheimer's disease. Neurosci Lett. (2006) 391:147-9. doi: 10.1016/j.neulet.2005.08.047

114. Walter S, Letiembre M, Liu Y, Heine H, Penke B, Hao W, et al. Role of the toll-like receptor 4 in neuroinflammation in Alzheimer's disease. Cell Physiol Biochem. (2007) 20:947-56. doi: 10.1159/000110455

115. Rietdijk CD, Van Wezel RJA, Garssen J, Kraneveld, A. D. Neuronal tolllike receptors and neuro-immunity in Parkinson's disease, Alzheimer's disease and stroke. Neuroimmunol Neuroinflammation. (2016) 3:27-37. doi: $10.20517 / 2347-8659.2015 .28$

116. Herber DL, Roth LM, Wilson D, Wilson N, Mason JE, Morgan D, et al. Time-dependent reduction in Abeta levels after intracranial LPS administration in APP transgenic mice. Exp Neurol. (2004) 190:245-53. doi: 10.1016/j.expneurol.2004.07.007

117. Tahara K, Kim HD, Jin JJ, Maxwell JA, Li L, Fukuchi K. Role of toll-like receptor signalling in Abeta uptake and clearance. Brain. (2006) 129:300619. doi: 10.1093/brain/awl249

118. Richard KL, Filali M, Prefontaine P, Rivest S. Toll-like receptor 2 acts as a natural innate immune receptor to clear amyloid beta 1-42 and delay the cognitive decline in a mouse model of Alzheimer's disease. J Neurosci. (2008) 28:5784-93. doi: 10.1523/JNEUROSCI.1146-08.2008

119. Okun E, Griffioen KJ, Mattson MP. Toll-like receptor signaling in neural plasticity and disease. Trends Neurosci. (2011) 34:269-81. doi: 10.1016/j.tins.2011.02.005

120. Reed-Geaghan EG, Savage JC, Hise AG, Landreth GE. CD14 and toll-like receptors 2 and 4 are required for fibrillar A\{beta\}stimulated microglial activation. J Neurosci. (2009) 29:11982-92. doi: 10.1523/JNEUROSCI.3158-09.2009

121. Doi Y, Mizuno T, Maki Y, Jin S, Mizoguchi H, Ikeyama M, et al. Microglia activated with the toll-like receptor 9 ligand $\mathrm{CpG}$ attenuate oligomeric amyloid \{beta\} neurotoxicity in in vitro and in vivo models of Alzheimer's disease. Am J Pathol. (2009) 175:2121-32. doi: 10.2353/ajpath.2009.090418

122. Beraud D, Maguire-Zeiss KA. Misfolded alpha-synuclein and Toll-like receptors: therapeutic targets for Parkinson's disease. Parkinsonism Relat Disord. (2012) 18(Suppl. 1):S17-20. doi: 10.1016/S1353-8020(11)70008-6

123. Kim C, Ho DH, Suk JE, You S, Michael S, Kang J, et al. Neuronreleased oligomeric alpha-synuclein is an endogenous agonist of TLR2 for paracrine activation of microglia. Nat Commun. (2013) 4:1562. doi: $10.1038 /$ ncomms 2534

124. Daniele SG, Beraud D, Davenport C, Cheng K, Yin H, Maguire-Zeiss KA. Activation of MyD88-dependent TLR1/2 signaling by misfolded alphasynuclein, a protein linked to neurodegenerative disorders. Sci Signal. (2015) 8:ra45. doi: 10.1126/scisignal.2005965

125. Fellner L, Irschick R, Schanda K, Reindl M, Klimaschewski L, Poewe W, et al. Toll-like receptor 4 is required for alpha-synuclein dependent activation of microglia and astroglia. Glia. (2013) 61:349-60. doi: 10.1002/glia.22437

126. Noelker C, Morel L, Lescot T, Osterloh A, Alvarez-Fischer D, Breloer M, et al. Toll like receptor 4 mediates cell death in a mouse MPTP model of Parkinson disease. Sci Rep. (2013) 3:1393. doi: 10.1038/srep01393

127. Campolo M, Paterniti I, Siracusa R, Filippone A, Esposito E, Cuzzocrea S. TLR4 absence reduces neuroinflammation and inflammasome activation in Parkinson's diseases in vivo model. Brain Behav Immunity. (2019) 76:236-47. doi: 10.1016/j.bbi.2018.12.003

128. Letiembre $\mathrm{M}$, Liu $\mathrm{Y}$, Walter $\mathrm{S}$, Hao $\mathrm{W}$, Pfander $\mathrm{T}$, Wrede $\mathrm{A}$, et al. Screening of innate immune receptors in neurodegenerative 
diseases: a similar pattern. Neurobiol Aging. (2009) 30:759-68. doi: 10.1016/j.neurobiolaging.2007.08.018

129. Casula M, Iyer AM, Spliet WG, Anink JJ, Steentjes K, Sta M, et al. Tolllike receptor signaling in amyotrophic lateral sclerosis spinal cord tissue. Neuroscience. (2011) 179:233-43. doi: 10.1016/j.neuroscience.2011.02.001

130. Lin YC, Chang YM, Yu JM, Yen JH, Chang JG, Hu CJ. Toll-like receptor 4 gene C119A but not Asp299Gly polymorphism is associated with ischemic stroke among ethnic Chinese in Taiwan. Atherosclerosis. (2005) 180:305-9. doi: 10.1016/j.atherosclerosis.2004.12.022

131. Dirnagl U, Iadecola C, Moskowitz MA. Pathobiology of ischaemic stroke: an integrated view. Trends Neurosci. (1999) 22:391-7. doi: 10.1016/S0166-2236(99)01401-0

132. Doyle KP, Simon RP, Stenzel-Poore MP. Mechanisms of ischemic brain damage. Neuropharmacology. (2008) 55:310-8. doi: 10.1016/j.neuropharm.2008.01.005

133. Hanisch UK, Johnson TV, Kipnis J. Toll-like receptors: roles in neuroprotection? Trends Neurosci. (2008) 31:176-82. doi: 10.1016/j.tins.2008.01.005

134. Muhammad S, Barakat W, Stoyanov S, Murikinati S, Yang H, Tracey KJ, et al. The HMGB1 receptor RAGE mediates ischemic brain damage. J Neurosci. (2008) 28:12023-31. doi: 10.1523/JNEUROSCI.2435-08.2008

135. Qiu J, Nishimura M, Wang Y, Sims JR, Qiu S, Savitz SI, et al. Early release of HMGB-1 from neurons after the onset of brain ischemia. J Cereb Blood Flow Metab. (2008) 28:927-38. doi: 10.1038/sj.jcbfm.9600582

136. Zhang J, Takahashi HK, Liu K, Wake H, Liu R, Maruo T, et al. Antihigh mobility group box-1 monoclonal antibody protects the blood-brain barrier from ischemia-induced disruption in rats. Stroke. (2011) 42:1420-8. doi: 10.1161/STROKEAHA.110.598334

137. Liu K, Mori S, Takahashi HK, Tomono Y, Wake H, Kanke T, et al. Anti-high mobility group box 1 monoclonal antibody ameliorates brain infarction induced by transient ischemia in rats. Faseb J. (2007) 21:3904-16. doi: 10.1096/fj.07-8770com

138. Gesuete R, Kohama SG, Stenzel-Poore MP. Toll-like receptors and ischemic brain injury. J Neuropathol Exp Neurol. (2014) 73:378-86. doi: 10.1097/NEN.0000000000000068

139. Hua F, Ma J, Ha T, Kelley JL, Kao RL, Schweitzer JB, et al. Differential roles of TLR2 and TLR4 in acute focal cerebral ischemia/reperfusion injury in mice. Brain Res. (2009) 1262:100-8. doi: 10.1016/j.brainres.2009.01.018

140. Shichita T, Hasegawa E, Kimura A, Morita R, Sakaguchi R, Takada I, et al. Peroxiredoxin family proteins are key initiators of post-ischemic inflammation in the brain. Nat Med. (2012) 18:911. doi: 10.1038/nm.2749

141. Bohacek I, Cordeau P, Lalancette-Hébert M, Gorup D, Weng Y-C, Gajovic S, et al. Toll-like receptor 2 deficiency leads to delayed exacerbation of ischemic injury. J Neuroinflamm. (2012) 9:191. doi: 10.1186/1742-2094-9-191

142. Cao CX, Yang QW, Lv FL, Cui J, Fu HB, Wang JZ. Reduced cerebral ischemia-reperfusion injury in Toll-like receptor 4 deficient mice. Biochem Biophys Res Commun. (2007) 353:509-14. doi: 10.1016/j.bbrc.2006.12.057

143. Caso JR, Pradillo JM, Hurtado O, Lorenzo P, Moro MA, Lizasoain I. Toll-like receptor 4 is involved in brain damage and inflammation after experimental stroke. Circulation. (2007) 115:1599-608. doi: 10.1161/CIRCULATIONAHA.106.603431

144. Reismann P, Lichy C, Rudofsky G, Humpert PM, Genius J, Si TD, et al. Lack of association between polymorphisms of the toll-like receptor 4 gene and cerebral ischemia. J Neurol. (2004) 251:853-8. doi: 10.1007/s00415-004-0447-7

145. Yang QW, Li JC, Lu FL, Wen AQ, Xiang J, Zhang LL, et al. Upregulated expression of toll-like receptor 4 in monocytes correlates with severity of acute cerebral infarction. J Cereb Blood Flow Metab. (2008) 28:1588-96. doi: $10.1038 / \mathrm{jcbfm} .2008 .50$

146. Urra X, Villamor N, Amaro S, Gomez-Choco M, Obach V, Oleaga L, et al. Monocyte subtypes predict clinical course and prognosis in human stroke. $J$ Cereb Blood Flow Metab. (2009) 29:994-1002. doi: 10.1038/jcbfm.2009.25

147. Brea D, Blanco M, Ramos-Cabrer P, Moldes O, Arias S, Perez-Mato $\mathrm{M}$, et al. Toll-like receptors 2 and 4 in ischemic stroke: outcome and therapeutic values. J Cereb Blood Flow Metab. (2011) 31:1424-31. doi: $10.1038 / \mathrm{jcbfm} .2010 .231$

148. Hyakkoku K, Hamanaka J, Tsuruma K, Shimazawa M, Tanaka H, Uematsu S, et al. Toll-like receptor 4 (TLR4), but not TLR3 or TLR9, knock-out mice have neuroprotective effects against focal cerebral ischemia. Neuroscience. (2010) 171:258-67. doi: 10.1016/j.neuroscience.2010.08.054

149. Brea D, Sobrino T, Rodriguez-Yanez M, Ramos-Cabrer P, Agulla J, Rodriguez-Gonzalez R, et al. Toll-like receptors 7 and 8 expression is associated with poor outcome and greater inflammatory response in acute ischemic stroke. Clin Immunol. (2011) 139:193-8. doi: 10.1016/j.clim.2011.02.001

150. Bsibsi M, Ravid R, Gveric D, Van Noort JM. Broad expression of Toll-like receptors in the human central nervous system. J Neuropathol Exp Neurol. (2002) 61:1013-21. doi: 10.1093/jnen/61.11.1013

151. Guo X, Harada C, Namekata K, Matsuzawa A, Camps M, Ji H, et al. Regulation of the severity of neuroinflammation and demyelination by TLR-ASK1-p38 pathway. EMBO Mol Med. (2010) 2:504-15. doi: $10.1002 / \mathrm{emmm} .201000103$

152. Crowley T, Fitzpatrick JM, Kuijper T, Cryan JF, O'toole O, O'leary OF, et al. Modulation of TLR3/TLR4 inflammatory signaling by the GABAB receptor agonist baclofen in glia and immune cells: relevance to therapeutic effects in multiple sclerosis. Front Cell Neurosci. (2015) 9:284. doi: $10.3389 /$ fncel.2015.00284

153. Lehnardt S, Lehmann S, Kaul D, Tschimmel K, Hoffmann O, Cho S, et al. Toll-like receptor 2 mediates CNS injury in focal cerebral ischemia. $J$ Neuroimmunol. (2007) 190:28-33. doi: 10.1016/j.jneuroim.2007.07.023

154. Prinz M, Garbe F, Schmidt H, Mildner A, Gutcher I, Wolter K, et al. Innate immunity mediated by TLR9 modulates pathogenicity in an animal model of multiple sclerosis. J Clin Invest. (2006) 116:456-64. doi: 10.1172/JCI26078

155. Lampropoulou V, Hoehlig K, Roch T, Neves P, Calderon Gomez E, Sweenie $\mathrm{CH}$, et al. TLR-activated B cells suppress $\mathrm{T}$ cell-mediated autoimmunity. $J$ Immunol. (2008) 180:4763-73. doi: 10.4049/jimmunol.180.7.4763

156. Marta M, Andersson A, Isaksson M, Kampe O, Lobell A. Unexpected regulatory roles of TLR4 and TLR9 in experimental autoimmune encephalomyelitis. Eur J Immunol. (2008) 38:565-75. doi: $10.1002 /$ eji.200737187

157. Fitzgerald DC, O'brien K, Young A, Fonseca-Kelly Z, Rostami A, and Gran B. Interferon regulatory factor (IRF) 3 is critical for the development of experimental autoimmune encephalomyelitis. J Neuroinflammation. (2014) 11:130. doi: 10.1186/1742-2094-11-130

158. Guo B, Chang EY, Cheng G. The type I IFN induction pathway constrains Th17-mediated autoimmune inflammation in mice. J Clin Invest. (2008) 118:1680-90. doi: 10.1172/JCI33342

159. Mellanby RJ, Cambrook H, Turner DG, O'connor RA, Leech MD, Kurschus FC, et al. TLR-4 ligation of dendritic cells is sufficient to drive pathogenic $\mathrm{T}$ cell function in experimental autoimmune encephalomyelitis. J Neuroinflammation. (2012) 9:248. doi: 10.1186/1742-2094-9-248

160. Gurney ME, Liu R, Althaus JS, Hall ED, Becker DA. Mutant CuZn superoxide dismutase in motor neuron disease. J Inherit Metab Dis. (1998) 21:587-97. doi: 10.1023/A:1005475206997

161. Banci L, Bertini I, Durazo A, Girotto S, Gralla EB, Martinelli M, et al. Metalfree superoxide dismutase forms soluble oligomers under physiological conditions: a possible general mechanism for familial ALS. Proc Natl Acad Sci USA. (2007) 104:11263-7. doi: 10.1073/pnas.0704307104

162. Kang J, Rivest S. MyD88-deficient bone marrow cells accelerate onset and reduce survival in a mouse model of amyotrophic lateral sclerosis. J Cell Biol. (2007) 179:1219-30. doi: 10.1083/jcb.200705046

163. Zhao W, Beers DR, Henkel JS, Zhang W, Urushitani M, Julien J-P, et al. Extracellular mutant SOD1 induces microglial-mediated motoneuron injury. Glia. (2010) 58:231-43. doi: 10.1002/glia.20919

164. Nguyen MD, D'aigle T, Gowing G, Julien JP, and Rivest S. Exacerbation of motor neuron disease by chronic stimulation of innate immunity in a mouse model of amyotrophic lateral sclerosis. J Neurosci. (2004) 24:1340-9. doi: 10.1523/JNEUROSCI.4786-03.2004

165. Albuquerque KF, Marinovic MP, Morandi AC, Bolin AP, Otton R. Green tea polyphenol extract in vivo attenuates inflammatory features of neutrophils from obese rats. Eur J Nutr. (2016) 55:1261-74. doi: $10.1007 / \mathrm{s} 00394-015-0940-\mathrm{z}$

166. Hong Byun E, Fujimura Y, Yamada K, Tachibana H. TLR4 Signaling inhibitory pathway induced by green tea polyphenol epigallocatechin-3gallate through 67-kDa laminin Receptor. J Immunol. (2010) 185:33-45. doi: $10.4049 /$ jimmunol.0903742 
167. Kim TH, Ku SK, Bae JS. Inhibitory effects of kaempferol-3-O-sophoroside on HMGB1-mediated proinflammatory responses. Food Chem Toxicol. (2012) 50:1118-23. doi: 10.1016/j.fct.2011.12.004

168. Bhaskar S, Shalini V, Helen A. Quercetin regulates oxidized LDL induced inflammatory changes in human PBMCs by modulating the TLR-NF-kappaB signaling pathway. Immunobiology. (2011) 216:367-73. doi: 10.1016/j.imbio.2010.07.011

169. Yilma AN, Singh SR, Morici L, Dennis VA. Flavonoid naringenin: a potential immunomodulator for Chlamydia trachomatis inflammation. Mediators Inflamm. (2013) 2013:102457. doi: 10.1155/2013/102457

170. Zhu HT, Bian C, Yuan JC, Chu WH, Xiang X, Chen F, et al. Curcumin attenuates acute inflammatory injury by inhibiting the TLR4/MyD88/NFkappaB signaling pathway in experimental traumatic brain injury. $J$ Neuroinflamm. (2014) 11:59. doi: 10.1186/1742-2094-11-59

171. Haddadi R, Nayebi AM, Eyvari Brooshghalan S. Silymarin prevents apoptosis through inhibiting the Bax/caspase-3 expression and suppresses toll like receptor-4 pathway in the SNc of 6-OHDA intoxicated rats. Biomed Pharmacother. (2018) 104:127-36. doi: 10.1016/j.biopha.2018.05.020

172. Choi YT, Jung CH, Lee SR, Bae JH, Baek WK, Suh MH, et al. The green tea polyphenol (-)-epigallocatechin gallate attenuates beta-amyloid-induced neurotoxicity in cultured hippocampal neurons. Life Sci. (2001) 70:603-14. doi: 10.1016/S0024-3205(01)01438-2

173. Park SJ, Song HY, Youn HS. Suppression of the TRIF-dependent signaling pathway of toll-like receptors by isoliquiritigenin in RAW264.7 macrophages. Mol Cell. (2009) 28:365-8. doi: 10.1007/s10059-009-0130-z

174. Lee JK, Kim SY, Kim YS, Lee WH, Hwang DH, Lee JY. Suppression of the TRIF-dependent signaling pathway of Toll-like receptors by luteolin. Biochem Pharmacol. (2009) 77:1391-400. doi: 10.1016/j.bcp.2009.01.009

175. Hirao K, Yumoto H, Nakanishi T, Mukai K, Takahashi K, Takegawa D, et al. Tea catechins reduce inflammatory reactions via mitogen-activated protein kinase pathways in toll-like receptor 2 ligand-stimulated dental pulp cells. Life Sci. (2010) 86:654-60. doi: 10.1016/j.lfs.2010.02.017

176. Hua F, Ma J, Ha T, Xia Y, Kelley J, Williams DL, et al. Activation of Toll-like receptor 4 signaling contributes to hippocampal neuronal death following global cerebral ischemia/reperfusion. J Neuroimmunol. (2007) 190:101-11. doi: 10.1016/j.jneuroim.2007.08.014

177. Wang X, Jung J, Asahi M, Chwang W, Russo L, Moskowitz MA, et al. Effects of matrix metalloproteinase-9 gene knock-out on morphological and motor outcomes after traumatic brain injury. J Neurosci. (2000) 20:7037-42. doi: 10.1523/JNEUROSCI.20-18-07037.2000

178. Kerfoot SM, Long EM, Hickey MJ, Andonegui G, Lapointe BM, Zanardo RC, et al. TLR4 contributes to disease-inducing mechanisms resulting in central nervous system autoimmune disease. J Immunol. (2004) 173:7070-7. doi: 10.4049/jimmunol.173.11.7070

179. Lucas SM, Rothwell NJ, Gibson RM. The role of inflammation in CNS injury and disease. Br J Pharmacol. (2006) 147(Suppl. 1):S232-40. doi: 10.1038/sj.bjp.0706400

180. Allan SM, Rothwell NJ. Cytokines and acute neurodegeneration. Nat Rev Neurosci. (2001) 2:734-44. doi: 10.1038/35094583

181. Morganti-Kossmann MC, Rancan M, Stahel PF, Kossmann T. Inflammatory response in acute traumatic brain injury: a double-edged sword. Curr Opin Crit Care. (2002) 8:101-5. doi: 10.1097/00075198-2002040 00-00002

182. Alfonso-Loeches S, Pascual-Lucas M, Blanco AM, Sanchez-Vera I, Guerri C. Pivotal role of TLR4 receptors in alcohol-induced neuroinflammation and brain damage. J Neurosci. (2010) 30:8285-95. doi: 10.1523/JNEUROSCI.0976-10.2010

183. Trotta T, Porro C, Calvello R, Panaro MA. Biological role of Tolllike receptor-4 in the brain. J Neuroimmunol. (2014) 268:1-12. doi: 10.1016/j.jneuroim.2014.01.014

184. Testa G, Gamba P, Badilli U, Gargiulo S, Maina M, Guina T, et al. Loading into nanoparticles improves quercetin's efficacy in preventing neuroinflammation induced by oxysterols. PLoS ONE. (2014) 9:e96795. doi: 10.1371/journal.pone.0096795

185. Nery-Flores SD, Mendoza-Magana ML, Ramirez-Herrera MA, RamirezVazquez JJ, Romero-Prado MMJ, Cortez-Alvarez CR, et al. Curcumin exerted neuroprotection against ozone-induced oxidative damage and decreased NF-kappaB activation in rat hippocampus and serum levels of inflammatory cytokines. Oxid Med Cell Longev. (2018) 2018:9620684. doi: $10.1155 / 2018 / 9620684$

186. Gutierres VO, Assis RP, Arcaro CA, Oliveira JO, Lima TFO, Beretta A, et al. Curcumin improves the effect of a reduced insulin dose on glycemic control and oxidative stress in streptozotocin-diabetic rats. Phytother Res. (2019) 33:976-88. doi: 10.1002/ptr.6291

187. Zhang Y, Zeng Y. Curcumin reduces inflammation in knee osteoarthritis rats through blocking TLR4 /MyD88/NF-kappaB signal pathway. Drug Dev Res. (2019). doi: 10.1002/ddr.21509

188. Youn HS, Saitoh SI, Miyake K, Hwang DH. Inhibition of homodimerization of Toll-like receptor 4 by curcumin. Biochem Pharmacol. (2006) 72:62-9. doi: 10.1016/j.bcp.2006.03.022

189. Yang F, Lim GP, Begum AN, Ubeda OJ, Simmons MR, Ambegaokar SS, et al. Curcumin inhibits formation of amyloid beta oligomers and fibrils, binds plaques, and reduces amyloid in vivo. J Biol Chem. (2005) 280:5892-901. doi: 10.1074/jbc.M404751200

190. Zhao L, Lee JY, Hwang DH. Inhibition of pattern recognition receptormediated inflammation by bioactive phytochemicals. Nutr Rev. (2011) 69:310-20. doi: 10.1111/j.1753-4887.2011.00394.x

191. Meng Z, Yan C, Deng Q, Gao DF, Niu XL. Curcumin inhibits LPS-induced inflammation in rat vascular smooth muscle cells in vitro via ROS-relative TLR4-MAPK/NF-kappaB pathways. Acta Pharmacol Sin. (2013) 34:901-11. doi: 10.1038/aps.2013.24

192. Zeng Z, Zhan L, Liao H, Chen L, Lv X. Curcumin improves TNBS-induced colitis in rats by inhibiting IL-27 expression via the TLR4/NF-kappaB signaling pathway. Planta Med. (2013) 79:102-9. doi: $10.1055 / \mathrm{s}-0032-1328057$

193. Farahani MS, Bahramsoltani R, Farzaei MH, Abdollahi M, Rahimi R. Plant-derived natural medicines for the management of depression: an overview of mechanisms of action. Rev Neurosci. (2015) 26:305-21. doi: 10.1515/revneuro-2014-0058

194. Kuang X, Huang Y, Gu HF, Zu XY, Zou WY, Song ZB, et al. Effects of intrathecal epigallocatechin gallate, an inhibitor of Toll-like receptor 4, on chronic neuropathic pain in rats. Eur J Pharmacol. (2012) 676:51-6. doi: 10.1016/j.ejphar.2011.11.037

195. Weinreb O, Amit T, Mandel S, Youdim MBH. Neuroprotective molecular mechanisms of (-)-epigallocatechin-3-gallate: a reflective outcome of its antioxidant, iron chelating and neuritogenic properties. Genes Nutr. (2009) 4:283-96. doi: 10.1007/s12263-009-0143-4

196. Singh NA, Mandal AKA, Khan ZA. Potential neuroprotective properties of epigallocatechin-3-gallate (EGCG). Nutr J. (2016) 15:60. doi: 10.1186/s12937-016-0179-4

197. Seong KJ, Lee HG, Kook MS, Ko HM, Jung JY, Kim WJ. Epigallocatechin3-gallate rescues LPS-impaired adult hippocampal neurogenesis through suppressing the TLR4-NF-kappaB signaling pathway in mice. Korean $J$ Physiol Pharmacol. (2016) 20:41-51. doi: 10.4196/kjpp.2016.20.1.41

198. Harold D, Abraham R, Hollingworth P, Sims R, Gerrish A, Hamshere ML, et al. Genome-wide association study identifies variants at CLU and PICALM associated with Alzheimer\&\#39;s disease. Nat Genetics. (2009) 41:1088. doi: $10.1038 /$ ng. 440

199. Galimberti D, Scarpini E. Inflammation and oxidative damage in Alzheimer's disease: friend or foe? Front Biosci. (2011) 3:252-66. doi: 10.2741/s149

200. Naj AC, Jun G, Beecham GW, Wang LS, Vardarajan BN, Buros J, et al. Common variants at MS4A4/MS4A6E, CD2AP, CD33 and EPHA1 are associated with late-onset Alzheimer's disease. Nat Genet. (2011) 43:436-41. doi: 10.1038/ng.801

Conflict of Interest Statement: The authors declare that the research was conducted in the absence of any commercial or financial relationships that could be construed as a potential conflict of interest.

Copyright $(2019$ Azam, Jakaria, Kim, Kim, Haque and Choi. This is an open-access article distributed under the terms of the Creative Commons Attribution License (CC $B Y)$. The use, distribution or reproduction in other forums is permitted, provided the original author(s) and the copyright owner(s) are credited and that the original publication in this journal is cited, in accordance with accepted academic practice. No use, distribution or reproduction is permitted which does not comply with these terms. 